\title{
The Case for Improving U.S. Computer Science Education
}

BY ADAMS NAGER AND ROBERT D. ATKINSON I MAY 2016

It is time for computer science to be seen as a core science on par with more traditional high school science offerings such as biology, chemistry, and physics.
Despite the growing use of computers and software in every facet of our economy, not until recently has computer science education begun to gain traction in American school systems. The current focus on improving science, technology, engineering, and mathematics (STEM) education in the U.S. school system has disregarded differences within STEM fields. Indeed, the most important STEM field for a modern economy is not only one that is not represented by its own initial in "STEM" but also the field with the fewest number of high school students taking its classes and by far has the most room for improvement-computer science.

Since computer science became an academic discipline in the late 1960s, the level of interest in the field and the number of students taking courses has grown in fits and starts. Currently in an upswing, computer science education in the United States looks poised for steady growth. However, there is the possibility that interest in the field could again wane like it did in 2003 following the burst of the tech bubble. To maintain the field's current momentum, the perception of computer science (CS) needs to shift from its being considered a fringe, elective offering or a skills-based course designed to teach basic computer literacy or coding alone. Instead, it is time for CS to be seen as a core science on par with more traditional high school offerings such as biology, chemistry and physics.

Furthermore, universities should capitalize on the growing interest in computer science and expand their offerings to accommodate the growing demand for courses in the field. Not only is computer science a powerful educational tool for fostering critical thinking, problem solving, and creativity, computer skills and competencies are in high demand among employers in a wide range of industries, not just the tech industry. Policy and 
program reforms are needed to support and maintain the groundswell of interest in computer science.

To this end, policymakers should reform curricula for existing technology classes to focus on core concepts of computer science in primary and secondary schools and provide resources to train and recruit high-quality CS teachers. All states should allow CS to count as either a math or science requirement, and more STEM-intensive public high schools that give students in-depth exposure to CS should be established to allow students with the aptitude and interest in computer science to more deeply explore the subject. Finally, universities should be incentivized to expand their offerings in computer science and prioritize retaining students interested in majoring, minoring, or taking courses in CS.

\section{THE CASE FOR COMPUTER SCIENCE EDUCATION}

Every academic subject, from Latin to art and from math to the humanities, has dedicated advocates (including the teachers who teach the subjects) who believe that the U.S. education system can be improved by dedicating more time to its study and conversely that the system would be gravely weakened by reducing exposure to the subject. Just look at the recent controversy President Obama ignited when he had the temerity to (rightly) say that it was more important to teach students advanced manufacturing skills than art history; art historians came out in force to express their righteous indignation. ${ }^{1}$

Given that there are a limited number of hours in the academic year, not every subjectmatter advocate can be right. Choices have to be made. Not making choices and continuing with status quo is in itself a choice. However, there is a strong argument to be made for putting relatively more focus on computer science (CS) and featuring it in every high school in the country.

Computer science challenges students and teaches them to approach problems in new and rigorous ways. If taught properly, computer science courses instill creativity, critical thinking skills, and logical reasoning. Its core concepts are broadly transferable, giving students the ability to apply skills to myriad problems, enabling them to pursue crossdisciplinary pursuits, and allowing them to learn about the world they live in. And, perhaps most importantly, computer science provides computational literacy and problem-solving skills that are desperately needed by the workforce. CS ensures that students are competitive and adaptable in the labor market, not just for jobs in computer science, but for many occupations that increasingly require "double-deep" skills.

\section{Broad demand for computer science in IT professions}

As technology plays a larger role in our world, growth in IT jobs has outstripped overall job growth. The widening and deepening of demand for computer scientists have led to aboveaverage wages and faster wage growth in this field relative to the others. In the last decade, IT occupations have grown by 36 percent. $^{2}$ Demand for these jobs has grown even faster, but there are simply not enough IT professionals to meet rapidly expanding demand. This gap between the supply and demand of IT workers is a major component of the national STEM shortage. There are over 545,000 unfilled jobs requiring technology skills; while 
these jobs demand a diverse set of STEM skills, many are jobs requiring the ability to solve problems with computers. ${ }^{3}$

\section{Figure 1: Job growth in IT and overall workforce $(2005=1)^{4}$}

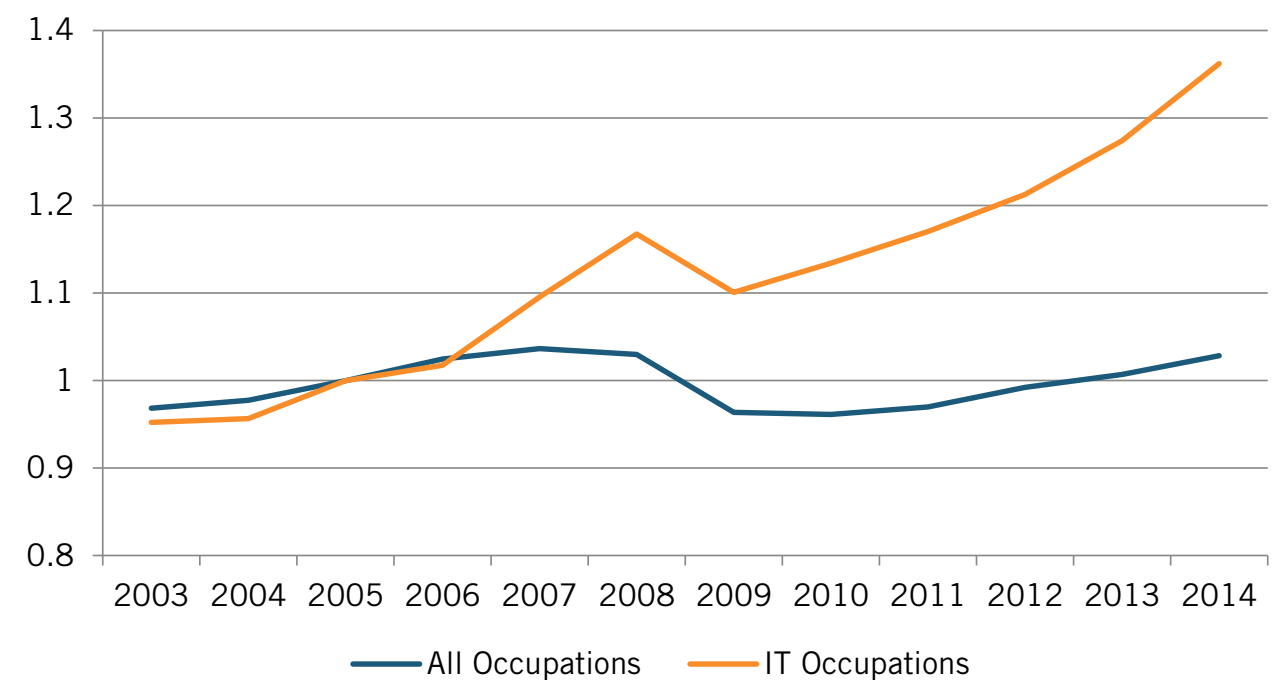

Eighty-one percent of computer science majors find jobs closely related to their fields; even during the recession there were two openings for every unemployed IT worker, and unemployment in computer occupations is now down to structural levels of 2.5 percent. ${ }^{5}$

In addition, many technology workers are not counted by official statistics. One study found that there were as many jobs using advanced technology skills in non-STEM industries (3.8 million) as there are in STEM industries (3.9 million), and that women are much more likely to use their technology skills in non-STEM industries. ${ }^{6}$

In the next ten years, job growth in the IT fields included in the official statistics is conservatively estimated to keep expanding by around 50,000 jobs per year. ${ }^{7}$ From 2005 to 2015, however, the economy added 100,000 IT jobs annually. ${ }^{8}$ In 2011, Code.org projected that the economy would add 1.4 million computing jobs by 2020 , but educate just 400,000 computer science students by then. ${ }^{9}$

In some cases, organizations may not pursue computer specialists because they know there are none available. Instead, they decide to not utilize new technologies and processes made possible by programmers because improvements do not make sense with labor so scarce. Moreover, the lack of knowledge among managers often means that those in charge are unaware of the benefits that could be brought to their organizations by computer specialists. As in many advanced industries, supply of workers skilled in computer science could continue to create its own demand long after the observed gap between supply and demand is corrected. It is hard to estimate when the market could be considered saturated, but it is clear that the United States is not near this point. 
Figure 2: Wage increases, total and in computer occupations, in 2014 dollars, 2003-2014 ${ }^{10}$

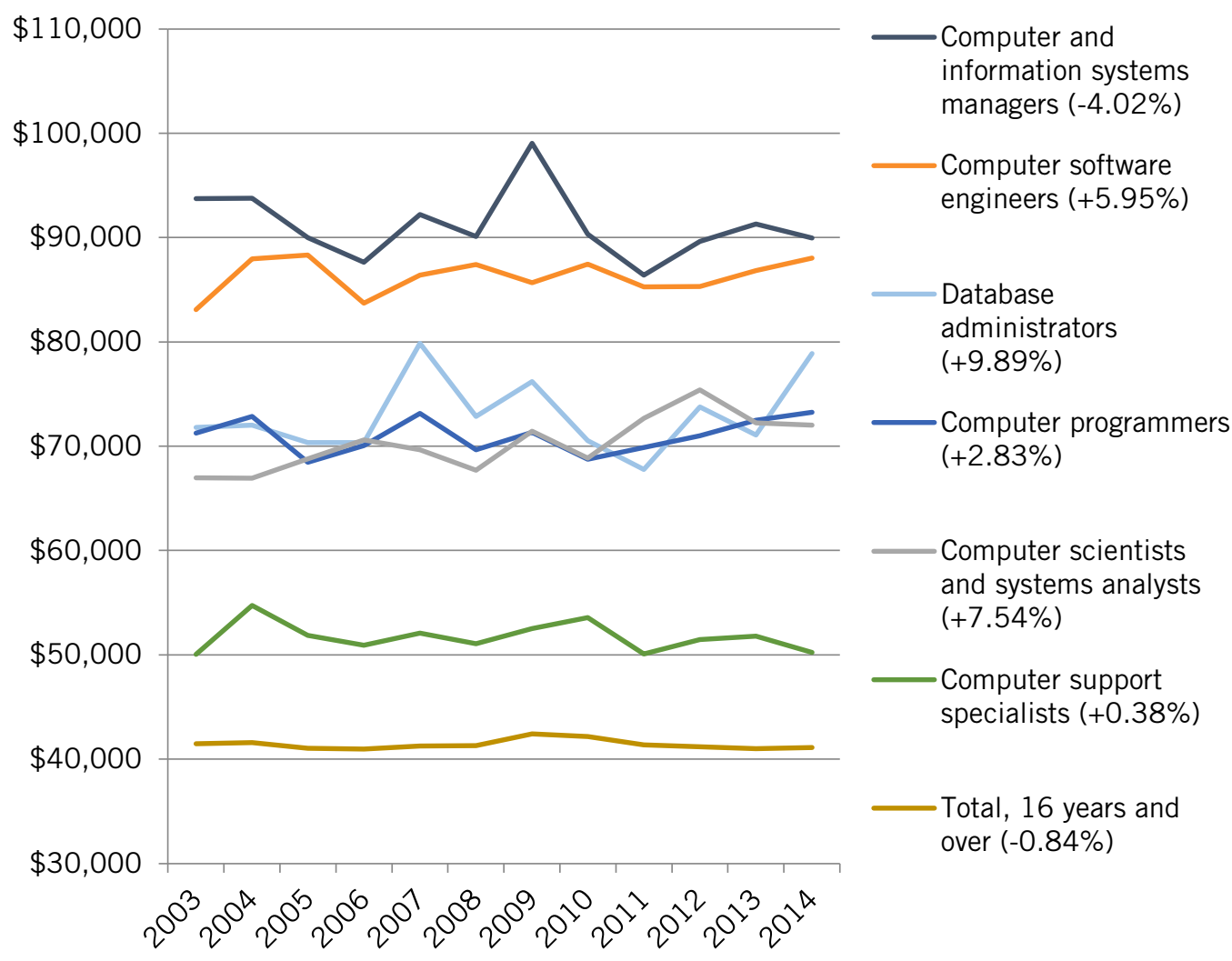

Not only has the economy been adding computer jobs, wages for computer and IT workers are rising. Since 2003 , real wages for U.S. occupations have decreased by 0.8 percent to an average of $\$ 41,132$, while real wages grew by 10 percent for database administrators, by 3 percent for computer programmers, and by 6 percent for software engineers. ${ }^{11}$ And with an average starting wage of $\$ 67,300$, computer science majors make 38 percent more than the average graduate straight out of college. ${ }^{12}$

\section{Broad demand for general knowledge of computer science}

Demand for computer science is not consigned just to IT professions. As Ed Lazowska, the Bill and Melinda Gates Chair in Computer Science and Engineering at the University of Washington, states: "Every field is becoming an information field, and if you can program at a level beyond an intro course, it's a huge value to you." ${ }^{13}$ Demand for computer knowledge is ubiquitous, and transforms traditional sectors across the economy. Many occupations, argues IT expert David Moschella, now require 'double-deep' skills, with training and expertise in technology and computing in addition to the skills traditionally demanded by these occupations. ${ }^{14}$

In today's technology-fueled economy, most industries rely on computer skills. ${ }^{15}$ Twothirds of computer jobs are in non-technology industries, such as healthcare, banking, or manufacturing. ${ }^{16}$ Organizations are increasingly technology-driven and technologydependent. For marketers, managers, bankers, designers, accountants, and others, coding 
experience and advanced understandings of computing technology are increasingly valuable. Professionals are learning technology and analytical skills and IT specialists are applying their focused skills onto a wide range of practical business applications. ${ }^{17}$ Similarly, workers in middle-skilled manufacturing jobs have a need for computer and technology skills. Workers with advanced computer knowledge who can use their experience to address and solve a host of problems and challenges are poised in succeed in a wide variety of fields.

\section{Pedagogical value of computer science}

Finally, computer science teaches intangible skills such as problem solving, logic, and critical thinking. It is also increasingly important for other STEM disciplines. Taught rigorously, computer science can serve as an avenue allowing students to more easily gain other science and mathematics skills. ${ }^{18}$ Parents agree. Ninety percent of parents think that computer science is a good use of resources at their child's school and want their student learning more computer science. Parents deem CS just as important as subjects like math and English, if not more so. ${ }^{19}$

One very useful aspect of computer science for teaching logic and reasoning is the subject's stepwise nature. Students writing an algorithm or line of code must address one problem at a time to provide a set of instructions that produce the desired outcome. Decomposition and debugging exercises teach invaluable lessons in how to reduce complex systems to individual parts and carefully examine how each part functions as part of a whole. When students identify potential solutions, they can run their algorithm and determine whether or not their code works. Having to master complex thought processes makes students better at solving problems in other subjects in much the same way that chess has been shown to have positive effects on problem solving and learning. ${ }^{20}$

Computer science also allows students to create models, develop hypotheses, test those hypotheses, and revise their models. Students who learn these skills by doing, writing or debugging code, are usually more engaged in computer science than they are in other subjects where they are lectured and then quizzed on knowledge. ${ }^{21}$

\section{The U.S. Pipeline for Computer Science Expertise}

The United States has three sources contributing to the base of computer science workforce: 1) the American education system; 2) immigration, especially in the form of $\mathrm{H}$ $1 \mathrm{~B}$ visas; and 3) job-skills training programs.

\section{Computer science graduates}

At current graduation rates of 50,962 bachelor's degrees, 22,777 master's degrees, and 1,826 Ph.D.'s in computer science, the supply of computer-science knowledge coming out of America's universities is insufficient to meet growing demand. ${ }^{22}$ (See figures 10 and 12.)

The challenge for U.S. schools is to widen the pipeline of computer science workers entering the labor force. To accomplish this, schools need to work on generating interest in computer science classes among a broader and more diverse group of students, improving 
There simply are not enough $H$-1B visas to satisfy demand for scarce IT talent. the quality of computer science classes, and expanding the number of available seats in CS classrooms on both the high school and university level.

Many university students taking computer science classes are foreign, and may not remain in the United States following graduation. This is especially true of graduate students. Five percent of bachelor's students and 49 percent of graduate students in computer science are foreign. ${ }^{23}$

The Optional Practical Training Program, which allows foreign STEM graduates to remain and work in the U.S. temporarily for 29 months, is used by 45 percent of foreign students. ${ }^{24}$ However, many students choose to go back to their home countries, and more are discouraged by the immigration process or are unable to get a long-term visa. While $\mathrm{H}$ $1 \mathrm{~B}$ visas can keep some of these graduates in the country temporarily, many are not selected through the H-1B lottery selection system and must return to their countries of origin. Twenty-three percent of foreign Ph.D. graduates in computer science leave the country within five years of graduating. ${ }^{25}$

At current rates, the supply of computer science workers still falls well short of the demand demonstrated by the current market, let alone demand expected to come.

\section{High-skilled immigration}

$\mathrm{H}-1 \mathrm{~B}$ visas, temporary guest worker visas intended for high-skilled workers to fill positions where the native workforce is insufficient, is the United States' vehicle for importing IT workers to help fill the STEM shortage.

$\mathrm{H}-1 \mathrm{~B}$ guest workers in IT fields have significant positive impacts on the U.S. economy. ${ }^{26}$ Research has shown that $\mathrm{H}-1 \mathrm{~B}$ workers do not undercut or lower American wages. In fact, wages for $\mathrm{H}-1 \mathrm{~B}$ guest workers tend to be comparable or slightly higher than wages for native workers. ${ }^{27}$

Given the large gaps between supply and demand for computer knowledge, $\mathrm{H}-1 \mathrm{~B}$ visas concentrate in IT industries. In fact, of the ten biggest $\mathrm{H}-1 \mathrm{~B}$ petitioners, nine are IT Consulting or Technology firms. Occupations in Systems Analysis and Programming, along with other computer-related occupations, accounted for 56.5 percent of all $\mathrm{H}-1 \mathrm{~B}$ visas awarded from 2013 to $2014 .{ }^{28}$ However, the 85,000 annual limit on $\mathrm{H}-1 \mathrm{~B}$ visas reduces the effectiveness of this program in filling the skills gap for IT workers. There simply are not enough visas to satisfy demand for scarce IT talent.

In years directly preceding and following the Great Recession, the H-1B cap, including the cap for master's graduates, the cap was reached in under one week. This forced U.S. Citizenship and Immigration Services to use a lottery system to award visas as they could not determine the order in which applications were received. In no year since the cap was lowered from 195,000 to 65,000 in Fiscal Year 2004 has the cap for either foreign workers or U.S. advanced degree holders not been reached. ${ }^{29}$ 
Table 1: Date H-1B Cap Reached, by Year (FY 2004-2016) ${ }^{30}$

\begin{tabular}{lcc}
\hline Cap Reached & Annual Cap (65,000) & $\begin{array}{c}\text { U.S. Master's or Higher Cap } \\
(20,000)\end{array}$ \\
\hline In one Week & $2008,2009,2014,2015$, & $2009,2014,2015,2016,2017$ \\
\hline Less than 3 Months & 2016,2017 & 2008,2013 \\
\hline Less than 9 Months & 2007,2013 & $2006,2007,2010,2011,2012$ \\
\hline Greater than 9 Months & $2005,2006,2010,2011,2012$ & \\
\hline
\end{tabular}

Retraining

Finally, retraining workers with new skills applicable in the new economy is essential. President Obama's recent "TechHire" initiative gives a boost to prospects for technology fields, especially advanced computer skills like coding, and many companies have their own retraining initiatives to secure a talented labor base. Initiatives like "coding boot camps" and rigorous massive open online courses (MOOCs) have the potential to help reduce the skills deficit, yet have three major shortcomings. ${ }^{31}$ MOOCs for adults regressively address problems inherent in our schools. More of the current workforce, especially younger professionals, should have received this education in the classroom. Moreover, these courses are typically designed to give only cursory training, and many concentrate on teaching a single coding language rather than giving in-depth knowledge and understanding of computing concepts. MOOCs and boot camps therefore can be useful for giving professionals basic computing or coding skills that complement other expertise; however, a brief coding seminar is no substitute for the years of education that an individual with a degree in CS possesses. And finally, MOOCs tend to benefit mainly the demographic populations already primed to succeed, and have been shown to be less effective in training women, minorities, and low-income individuals. ${ }^{32}$

\section{COMPUTER SCIENCE IN THE HIGH SCHOOL}

For all the reforms aimed at aiding the evolution and adoption of high school science, actual classes offered have remained relatively static over the last century. Educators have not integrated computer science into the standard progression of high school science courses. However, given the demand for computer expertise in the workplace and the pedagogical value of concepts conveyed through computer science classes, computer science offers a powerful tool both to teach scientific thinking and to prepare students for needed jobs. Today, numerous barriers in the American education system prevent students with both the aptitude and interest in CS from pursuing the field at the high school level.

\section{Establishment of the high school science status quo}

High school education became commonplace for American students between 1910 and 1940 , with enrollment in secondary school growing by 50 percent in the inter-war years. ${ }^{33}$ Laws raising the age at which a student could drop out of school contributed to this rapid 
Biology class was a tool

for students to obtain

knowledge from a

careful observation of

nature, which spoke to

both the agrarian focus

of American society and

a focus on teaching

students to think like

scientists. growth, but much of the reason for the increase was the sweeping change to the economy as agricultural jobs declined. While 41 percent of the American workforce was employed in agriculture in 1900 , by the end of the WWII that number was down to 16 percent. ${ }^{34} \mathrm{New}$ demand for educated labor, increased urbanization, and greater family wealth helped fuel demand for secondary education, and government focused on making secondary schooling free and accessible to all.

Science education curriculum in this period was heavily influenced by a National Education Association task force, referred to as the Committee of Ten, which decided in 1893 that biology should be the first science course taken by American high school students, followed by chemistry and physics. The Committee aimed to standardize and unify college entry requirements by issuing standards on what each course was to teach. Biology, in the eyes of the Committee of Ten, should be comprised of zoology, botany, and physiology. The Committee's curriculum called for students to spend 60 percent of classroom time engaged in laboratory and experiment components and stipulated that students should make careful sketches and drawings of the specimens they were examining. As such, biology class was a tool for students to obtain knowledge from a careful observation of nature, which spoke to both the agrarian focus of American society at the time and a focus on teaching students to think like scientists. The Committee also designated curricula for chemistry and physics classes that would follow biology in the high school science hierarchy.

The Committee of Ten's dictates on science were revolutionary for their time and played a major role in early emphasis on and promotion of science. The Committee suggested that 25 percent of class time be spent on science in American high schools, an ambitious mark for the time and one not commonly met today. ${ }^{35}$ Furthermore, its focus on experiments and scientific concepts over rote memorization represented an understanding of the importance of fostering intellectual curiosity through the framework of the scientific method.

The decision to prioritize biology as the first subject learned was not unanimous even in 1893. Several members of the committee proposed that biology come after chemistry and physics, suggesting students learn the underlying principles of science before applying them to the real world. Biology was ultimately selected because it was deemed the most powerful tool to communicate the underlying principles of science to high school freshmen. In that era, it made sense to use the natural world to teach students to communicate scientific ideas, conduct experiments, and evaluate scientific arguments. ${ }^{36}$

The reliance on the biology-chemistry-physics framework for American high school science education continues to this day. Today, biology is still commonly taught in the first year of high school (though contrary to the Committee of Tens' intentions the course today emphasizes rote memorization of facts and has light emphasis on rigorous labs) and is typically followed by chemistry and physics. The decision made in the nineteenth century still has a major impact on today's curriculum-95.6 percent of high school students take 
biology, compared to 70.4 percent taking chemistry and just 36.1 percent taking physics. ${ }^{37}$ Ambitious and talented students can, after completing the basic curriculum, choose to take Advanced Placement (AP) courses building off of these basic classes. Just like in math, advanced students are making it through more science courses than ever before. ${ }^{38}$ However, most students do not manage to find room in their schedules as juniors or seniors to take computer science. ${ }^{39}$

When computer science first emerged as a new scientific course of study in the mid-1980s, the established trio of sciences-biology, chemistry and physics-left little room in schedules for the new offering. While STEM as a whole has flourished as the visible need for STEM skills in the economy has increased over the last 25 years, computer science has been largely excluded from this growth.

\section{Figure 3: Percentages of high school students taking courses in math and science,} $1990-2009^{40}$

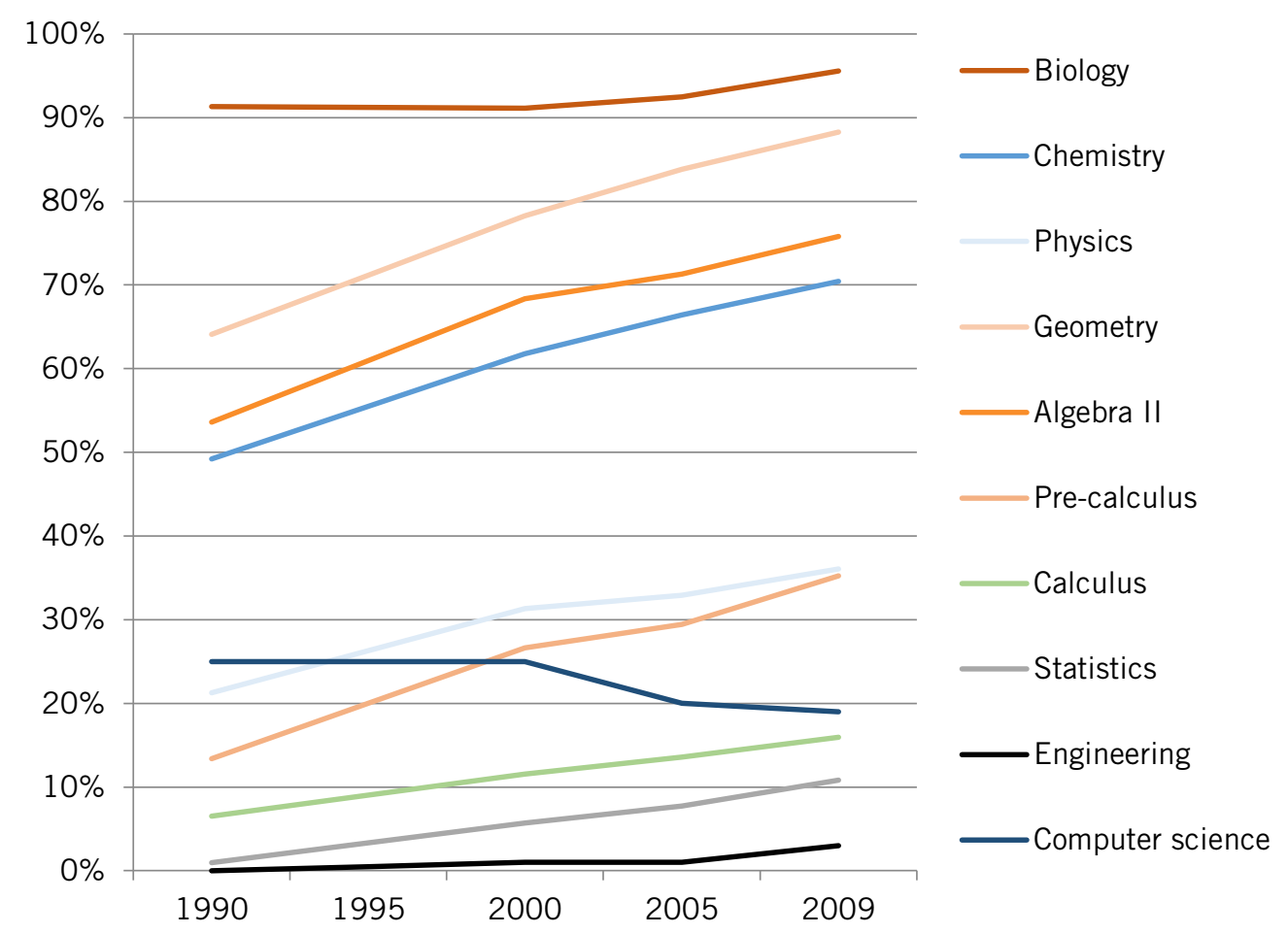

Following the launch of Sputnik in 1957, recognition of the importance of science and math education sparked a drive to dramatically expand and improve existing STEM education in primary and secondary schools. However, not until the 1980s did the National Science Foundation first raise flags of warning about a future shortage of workers adequately trained in math and science. ${ }^{41} \mathrm{~A}$ greater attention to these subjects became a national priority, and students began to take more math and science courses. For example, from 1990 to 2009, the share of students taking calculus increased from 7 percent to 17 percent, and the share of students taking a class in chemistry rose from 49 percent to 70 
In California more high school students take ceramics than take computer percent. Meanwhile, computer science was the only math or science field to lose ground, sinking from 25 percent of students in 1990 to 19 percent in 2009. (See figure 3.)

A proposal for education reform in 1983 from the National Commission on Excellence in Education recommended that a half-year of computer science enter the high school science curriculum, accompanying three years of science and three years of math as requirements for graduation. This, however, was ignored. ${ }^{42}$

By the late 1990s, most schools elected to use the computers they put in classrooms to teach "technology" courses, which typically featured lessons and drills in typing and review of basic word processing and spreadsheet software. Others added computer coding, which is only a fraction of what a rigorous CS curriculum should entail. Unfortunately, curriculum and standards still focus on using, rather than understanding, technology. In fact, only 37 percent of states' CS standards include a focus on computing concepts, while 73 percent of state CS standards include a focus on computer skills. ${ }^{43}$ Such classes teach computer literacy and basic skills but fail to impart the core concepts behind computer science. Since the advent of computers in classrooms, curricula in technology classrooms have evolved slowly, and many courses still focus on these basic skills even as familiarity with computers has become nearly ubiquitous, including among young children. While 19 percent of students take some form of technology course, the percentage taking courses that truly qualify as CS may be lower. One analysis focusing on the state of California found that only 1.8 percent of high school students are enrolled in computer science or programming courses (another 1 percent are enrolled in some form of related course, including game design, robotics, or engineering). In California, regarded as the epicenter of the technology revolution, more students take ceramics than take CS. ${ }^{44}$ Yet, there are 41,000 potters in the U.S. (making an average of just $\$ 30,000$ a year) with the number expected to decline by $2024 .{ }^{45}$ In contrast, just one CS sub-occupation, computer system analysts, employs 568,000 workers at an average salary of $\$ 82,710$ with job growth to 2024 projected to be "much faster than average." ${ }^{46}$

Today, however, technology has progressed far beyond the need for these basic skills as technology and computers plays an ever greater role in our lives and the education process. Students develop typing and word processing skills as they complete writing assignments for English and history classes. Students increasingly use spreadsheets in math and statistics classes, and presentation software is ubiquitously used for in-class student presentations. Students generally can master these programs as a requisite to complete other assignments. Coding is a useful skill, but computing languages come and go, and may even be obsolete before students reach the job market. Knowledge of coding is less useful for the longer term than an understanding of what makes the code work.

\section{High School Computer Science Today}

The last study of high school transcripts completed by the National Center for Educational Statistics in 2009 found that only 19 percent of high school seniors took some form of computer class, down 6 percentage points from $2000 .{ }^{47}$ Moreover, these courses revealed a 
serious gender gap, with only 14 percent of female students taking a computer course compared to 24 percent of males. Nationally, 3,075 schools are accredited to teach advanced placement (AP) computer science, out of 16,811 schools accredited to offer AP exams. While this is up by 66 percent from the 2007/2008 school year, it is still only 18 percent of total schools offering APs. By contrast, 76 percent of AP accredited schools teach AP calculus. ${ }^{48}$ The United States needs almost 10,000 additional teachers trained to teach computer science and provided with supportive resources in order to match access to high quality CS to access to calculus in high schools.

The ideal course in computer science is a lot more advanced than either computer literacy or coding. Rather, the best courses focus on underlying scientific principles, give students experience with thinking logically through abstractions, and communicate fundamental knowledge of how software and computing work. These classes introduce topics such as algorithms, programming paradigms, and data structures; they teach students how to think logically through problems, debug code, and apply knowledge to real world projects. ${ }^{49}$

\section{Figure 4: AP test takers in science and math by subject, $2015^{50}$}

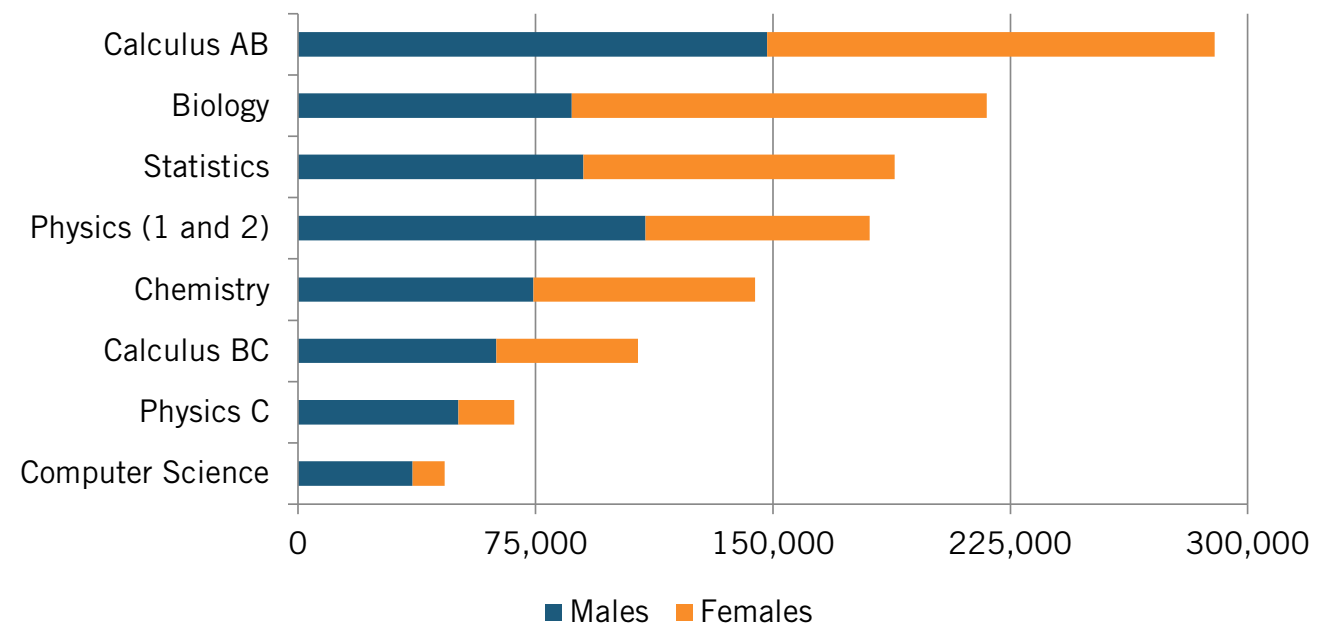

As early technology was adopted, some classes developed to teach more advanced concepts to high school students. Specifically, the Advanced Placement (AP) exam teaches basic principles of computer science, including coding and core concepts behind how computers actually work. First introduced in 1984, the AP CS exam tested students on the Pascal programming language, then $\mathrm{C}++$ from (2000 to 2003), and now tests based on Java (2003-present). However, interest and enrollment in the class has stayed static for much of its 30-year history. In fact, enrollment declined by over 5 percent from 2001 to 2011, and from 1990 to 2011 steadily declined as a percentage of total AP exams, excluding the spike in 1999 likely caused by both the tech bubble and the switch to C++. ${ }^{51}$ In 2006, 28 percent of students taking an AP computer science course opted to take the more difficult $\mathrm{CS} A B$ test, which required more in-depth knowledge of data structures and algorithms. However, the AB test was discontinued in 2009 due to low numbers of students. At present, no national framework or curriculum (outside of the AP exam) that attempt to raise the standard of computer science courses has been broadly adopted, though several 
suggested plans have been developed..$^{52}$ And as of 2010, only sixteen states had over 50 percent adoption of standards focusing on computing concepts. ${ }^{53}$ Moreover, the focus around Java has led to questions about how effective this AP CS curriculum is in teaching real concepts instead of more narrow knowledge of specific programs or software packages, leading a British report on international computer science to call the exam "rather narrow." 54

Figure 5: AP Computer Science Test Takers, Total and as a Percentage of All AP Tests, $1990-2015^{55}$

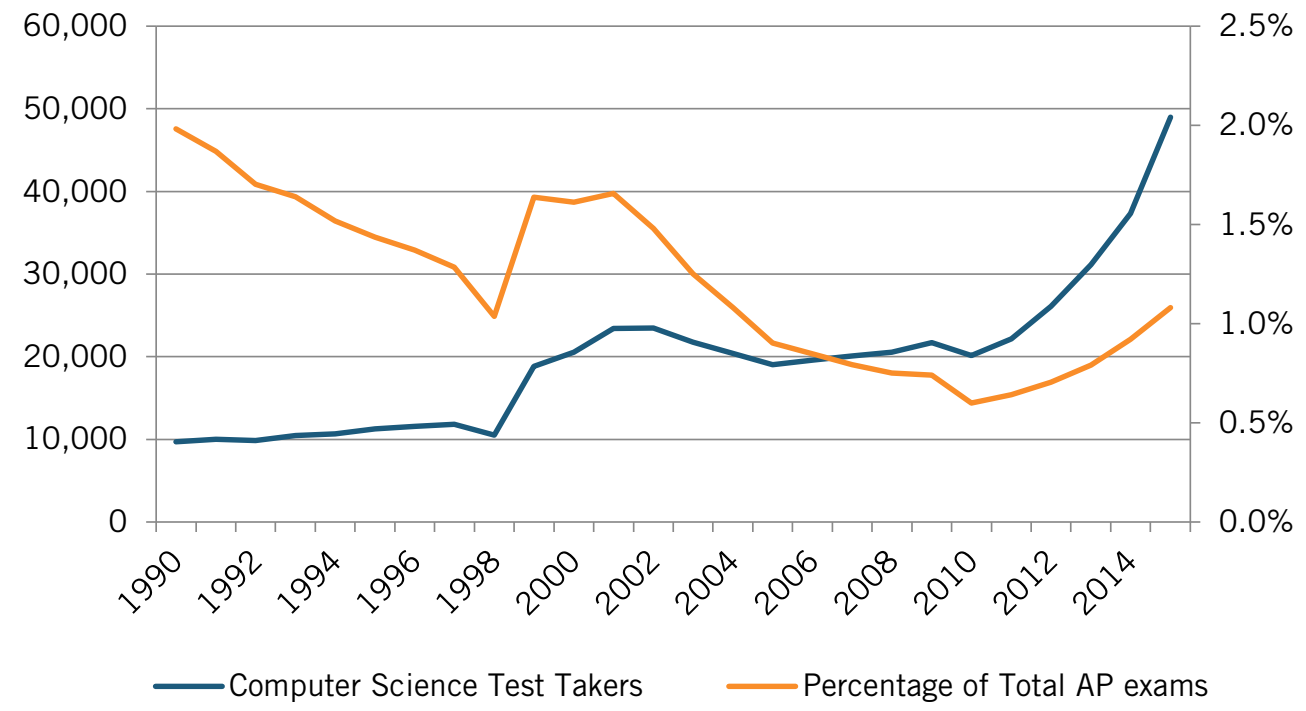

The new AP exam, Computer Science Principles, which will be launched in the fall of 2016, represents a step in the right direction. ${ }^{56}$ As opposed to the existing AP exam, which tests students in Java, the AP CS Principles course offers a language-agnostic, holistic view of computer science, focusing less on the syntax of a single programming language and more on the principles and interdisciplinary nature of computer science. The course also covers computing concepts such as algorithms and abstractions, introduces students to issues surrounding cybersecurity and the impact of the internet, and seeks to give students a framework for using computing to approach a wide variety of problems. ${ }^{57}$

\section{Lack of women and minorities in high school computer science}

As courses get more serious and move away from required technology courses light on real computer science, the gender ratio becomes even more skewed. Only 21.9 percent of students in AP computer science courses are female, the most egregious gender skew of any AP course. ${ }^{58}$ These rates contribute directly to wide gender gaps in the labor market where 76 percent of U.S. workers in computer occupations are male. ${ }^{59}$ Social encouragement, self-perception, academic exposure, and career perception all play into whether females will pursue CS. ${ }^{60}$ Reaching girls before high school is important, as those who take AP CS in high school are more than 10 times more likely to major in Computer Science than those who do not. ${ }^{61}$ 
Minorities also take the AP computer science course at low rates even when compared to other science courses. ${ }^{62}$ Only 3.8 percent of AP computer science students are black and only 9.2 percent are Hispanic, compared to 5.8 percent and 14.1 percent respectively in AP Calculus $\mathrm{AB}$ and 7 percent and 17.4 percent respectively of all AP students. ${ }^{63}$ If females and minority students took computer science at the rate of white and Asian males, the number of computer science exam-takers would increase by over 130 percent.

Figure 6: AP test takers by race, $2015^{64}$

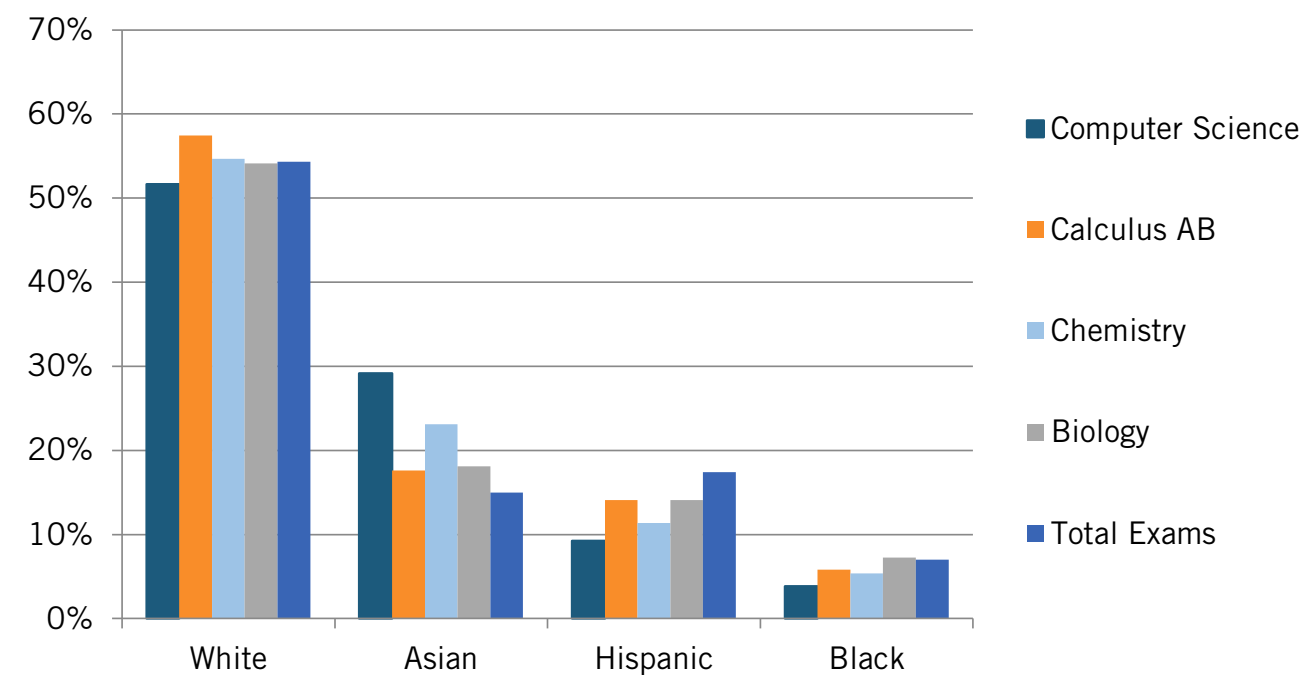

Figure 7: Students in STEM Advanced Placement courses by race, $2015^{65}$

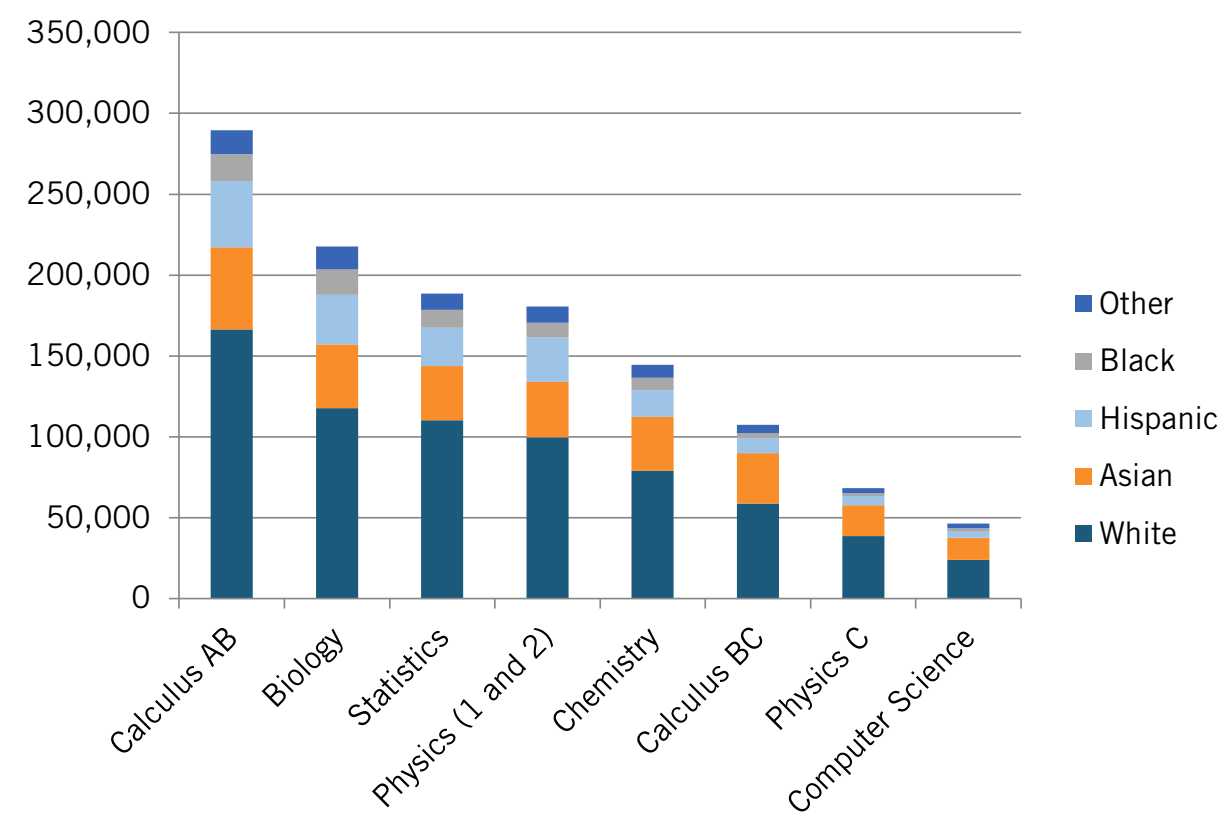

There are also large deviations in performance on the test. AP exams are scored on a 1 to 5 scale, with scores above 2 considered to be passing grades. While all tests aim for a normal score distribution, the AP computer science exam has the widest standard deviation of any $\mathrm{AP}$ test, and the highest proportion of students receiving a 1, the lowest possible score (over 
31 percent of students). For minorities, the failure rate is even more pronounced, with over 53 percent of Hispanic students and 59 percent of black students receiving 1s, again the highest proportion of any AP exam. For female minority students, these rates are even more extreme, with 65 percent of Hispanic girls and 68 percent of black girls receiving 1's.

Figure 8: Average scores on AP Computer Science exam by ethnicity and gender, $2015^{66}$

5

4

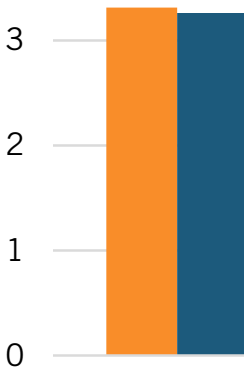

Asian

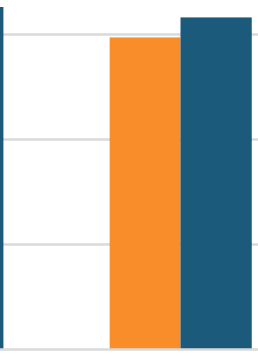

White

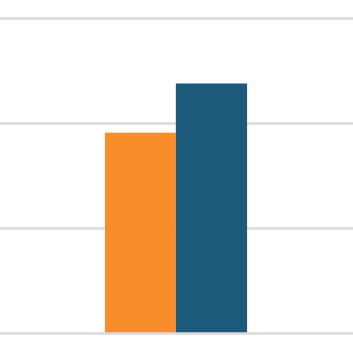

Hispanic

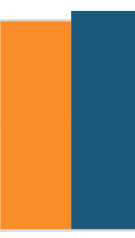

Black

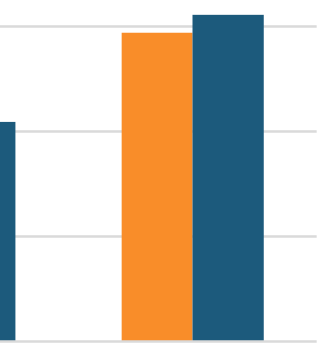

Total

- Female Male

Figure 9: Percent of Students Receiving Lowest Possible Score on AP Computer Science exam by gender and race, $2015^{67}$

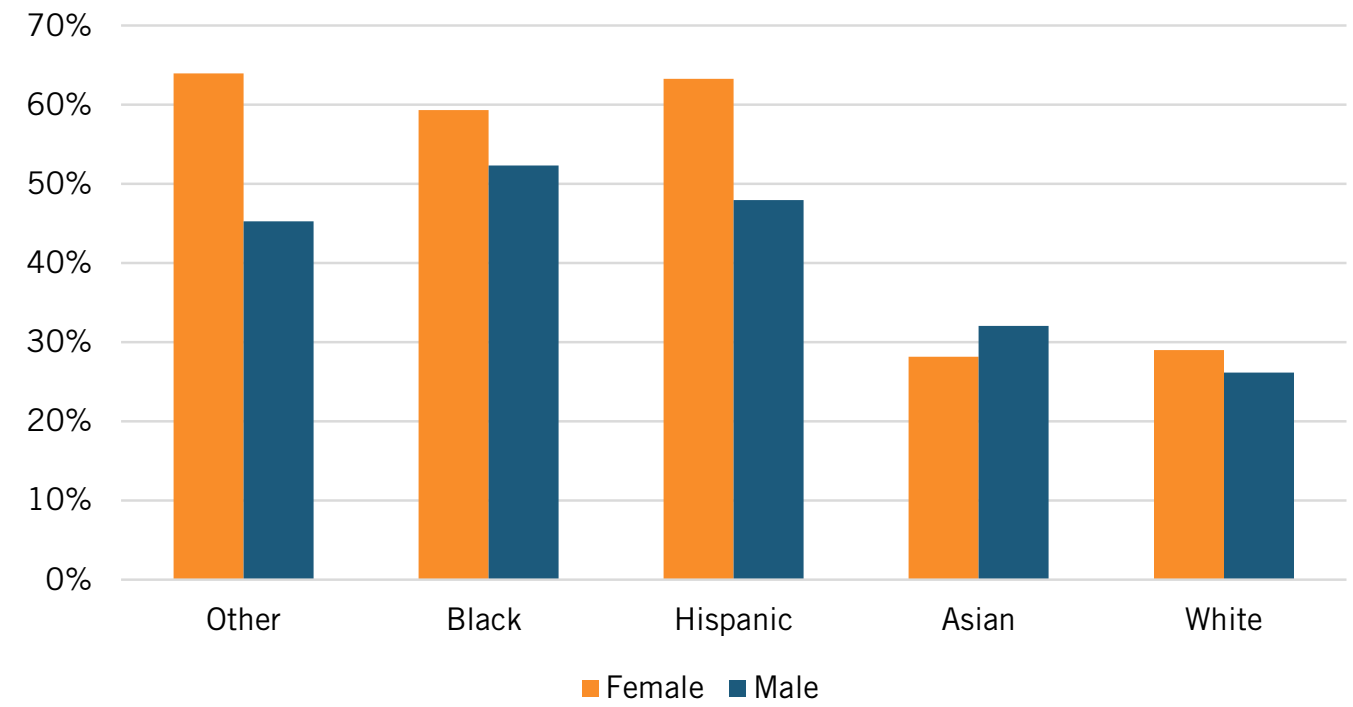

This wide disparity between students who do well and those who do not implies that the quality of many AP computer science courses is highly variable and that many students of advanced computer science courses do not receive adequate instruction.

Crowded out: Computer science as an elective

Today, computer science education, regardless of whether it is true CS or more vocational and skills-based training, is still secondary to the standard science education track. As a 


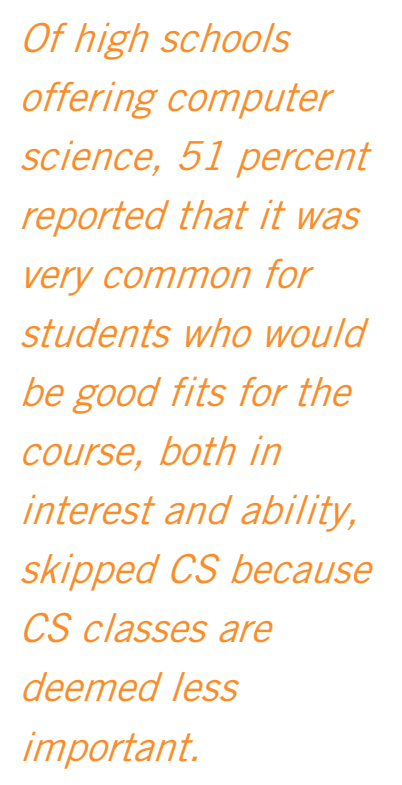

result, until recently, and in virtually all high schools, computer science was designated as a class to be taken only after completing core requirements. Fortunately, more states are making room in the curriculum by revising laws to allow CS to fulfill a graduation requirement. To date, 28 states and the District of Columbia allow computer science to count as either a math or science graduation requirement. ${ }^{68}$ This is up from nine states in $2010 .{ }^{69}$ More states are rightly considering making this change.

Computer science is frequently viewed as a course to take only after exhausting other science and math options, and college-bound students are often encouraged to take second courses in biology, chemistry, or physics instead of a CS course. Together with the persisting stigma that equates computer science with "geekiness" and the perceived difficulty of learning CS, the fact that many states still treat computer science as an elective instead of a requirement make CS a class that few students are able to or want to take. Of schools offering computer science, 51 percent reported that students who would be good fits for the course, both in interest and ability, skip CS because its classes are deemed less important. ${ }^{70}$

Additionally, CS teachers are often not accredited and provided with few resources. ${ }^{71}$ Because many schools offer only a single CS course, teachers for these courses commonly have their main focus in another field. These teachers may not have the deep expertise or time to focus on creating an enriching curriculum and stimulating class environment. The class can only go as deep as the teacher's bank of knowledge. As a result, only a very narrow group of high school students ever take computer science classes that provide a solid ground in computer science principles and practices. $^{72}$

It is not that white and Asian males crowd out female and minority would-be CS students - in many schools the barrier to expanding CS enrollment is not insufficient class spots but too little demand for the subject among students to justify creating a class at all. Even where CS classes are offered, schools have trouble finding enough students who fit the criteria to sign up for courses, leading to low class sizes (14.8 students per teacher taking the AP course in 2014, though this was up by 75 percent from 2008). ${ }^{73}$ As noted above, this is in part because students have little room for an elective course like CS given the increase in required courses. ${ }^{74}$

Making computer science an option for fulfilling STEM requirements, is a good way to get more students and more diversity into computer science. ${ }^{75}$ Moreover, such initiatives have broad popular support-77 percent of voters in Washington State supported making computer science count as a core math and science course rather than an elective. ${ }^{76}$ In the first year of counting the course toward graduation requirements, individual school districts have seen enrollment in computer science course jump by as much as 50 percent. ${ }^{77}$

\section{Teacher training and limited educational resources}

When high school CS courses are offered, the quality of teaching is often limited. Simply put, individuals who have adequate computer science knowledge, the pedagogical 
While in 2003, women received 36.9 percent of computer science bachelor's degrees, in 2013 that number was down to 21.7 percent. knowledge required to be a good teacher, and are willing to work for wages far below what their skill sets could command on the open market are rare.

The early generations of high school CS teachers were largely teachers of other subjects with an enthusiasm for computers. ${ }^{78}$ In many cases, teachers had not themselves taken more conceptual computer science classes as part of their education. As standards and certifications improve, teachers are more likely to have formal educations in computer science. This evolution is vital to the success of computer science education.

A survey of schools offering computer classes showed that only 34 percent of high schools with computer classes offered a course where debugging was a core concept, only 32 percent offered a course featuring analysis of algorithms, and 36 percent had a course including data structures. ${ }^{79}$ This is a symptom of the "some STEM for all" approach, in which classes using technology are mandated in the curriculum but standards are not put in place and resources are not provided to ensure quality classes with teachers who are prepared to teach the course.

One major barrier to increasing the quantity and quality of CS courses offered to high school students is teacher certification. Students in graduate education programs choose the subjects in which they certify. However, in 29 states, computer science is not even an option. Therefore, teachers who end up in classrooms are either uncertified or certified for another subject. Even in the states with certification, most (12 of 21) do not require certification to teach CS subjects, as they worry that the introduction of this requirement could reduce the already limited supply of CS teachers. Only Arizona, Wisconsin, and the District of Columbia require certification for all CS teachers. ${ }^{80}$

The United States should aim to have high-quality CS courses as common in high schools as calculus courses. To do so, the United States needs to train and certify 10,000 additional CS teachers. The CS10K non-profit initiative, seeks to do just that-train instructors to teach in-depth computer science courses using rigorous curricula. ${ }^{81}$ However, quality computer science teachers cannot be created overnight. Like any serious academic subject, computer science is a rigorous discipline, not to be mastered over only a few weeks of training. Moreover, most graduates with computer science degrees could find much higher compensation in other fields. Recruiting and training quality teachers is a major barrier to extending access to computer science across all schools, and an impediment to blanket mandates by school districts that seek to offer computer science courses in every school.

\section{COMPUTER SCIENCE IN THE UNIVERSITY}

Computer science in U.S. colleges and universities faces a unique set of challenges and opportunities. Unlike in American high schools, where computer science education is deemed sub-par, the United States boasts strong tertiary computer science programs that draw students from across the globe. Moreover, the number of college and university students taking classes and pursuing majors in computer science is growing quickly. However, challenges remain, including how to fully take advantage of the increase in interested students and how to expand enrollment among women and minorities. 
Tertiary computer science education has seen spurts of growth, but the overall rate of growth has been torpid considering the magnified role computers and technology have on every aspect of our lives. For about half of the last decade, computer science as a college major has been in sharp decline. From 2004 to 2009, the share of computer science majors fell by 30 percent for males and 55 percent for females. Since then, the number of males has largely recovered, and is just 5 percent below 2004 numbers. However, the number of females majoring in computer science remains 39 percent below the 2004 peak. While in 2003, women received 36.9 percent of bachelor's degrees in CS, in 2013 that number was down to 21.7 percent. $^{82}$

Much of the success of university computer science departments comes from the ability of high schools to expose students to computer science and get them thinking about the subject as a possible major and career. Currently, only two percent of high school students have an accurate impression of what computer science majors learn. ${ }^{83}$ Lack of information about the nature of CS and its usefulness in the workforce severely limit that number of students seeking to study CS. Students who took the AP computer science exam are eight times more likely to major in computer science than other incoming freshmen. Even if students do not take a CS class themselves, the presence of a computer science course in the high school alerts students that computer science is a possible career path, and increases their likelihood of experimenting with the discipline later. ${ }^{84}$

Figure 10: Bachelor Degrees in Computer Science, 1971-2013 ${ }^{85}$

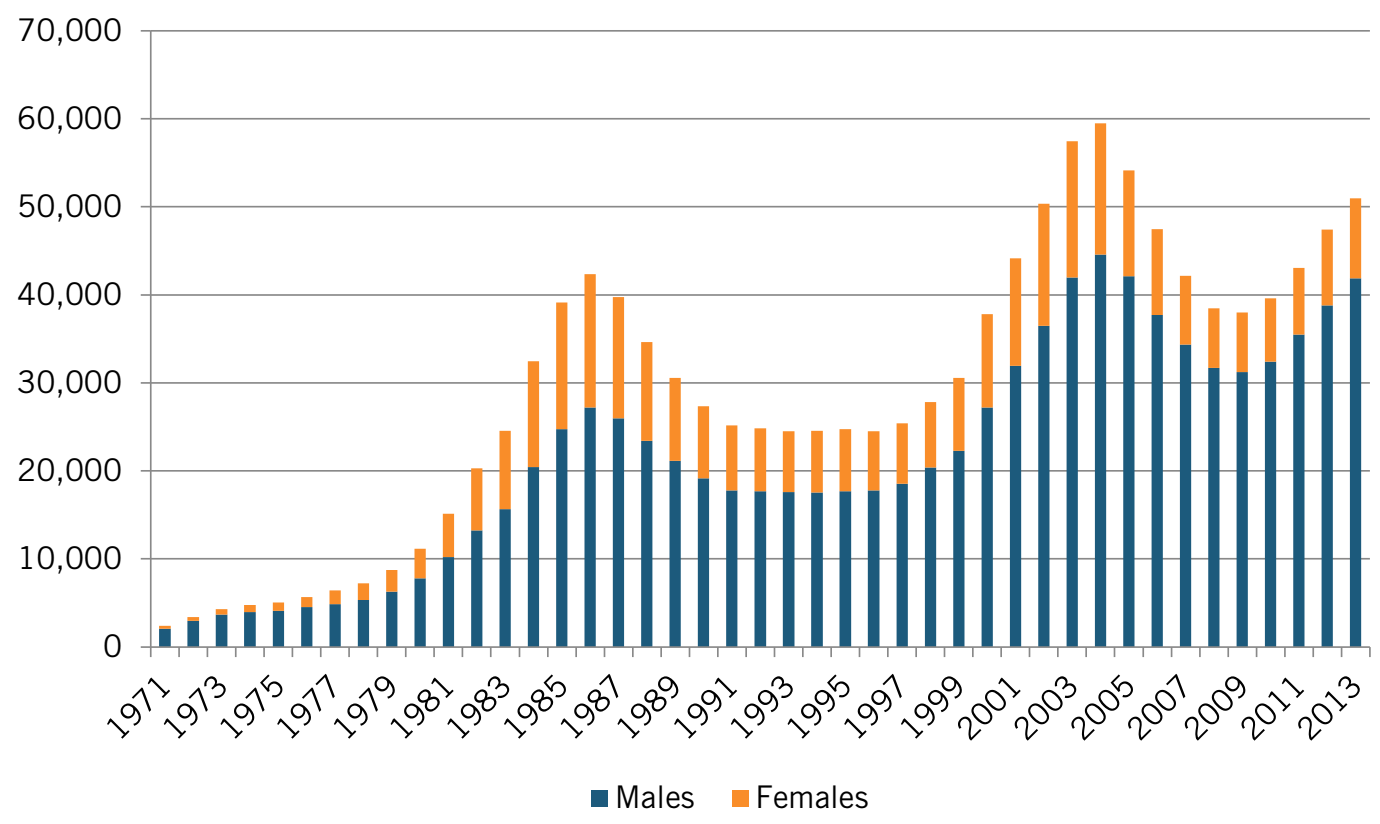


Figure 11: Percent of total university graduates majoring in computer science, 1997-2013 ${ }^{86}$

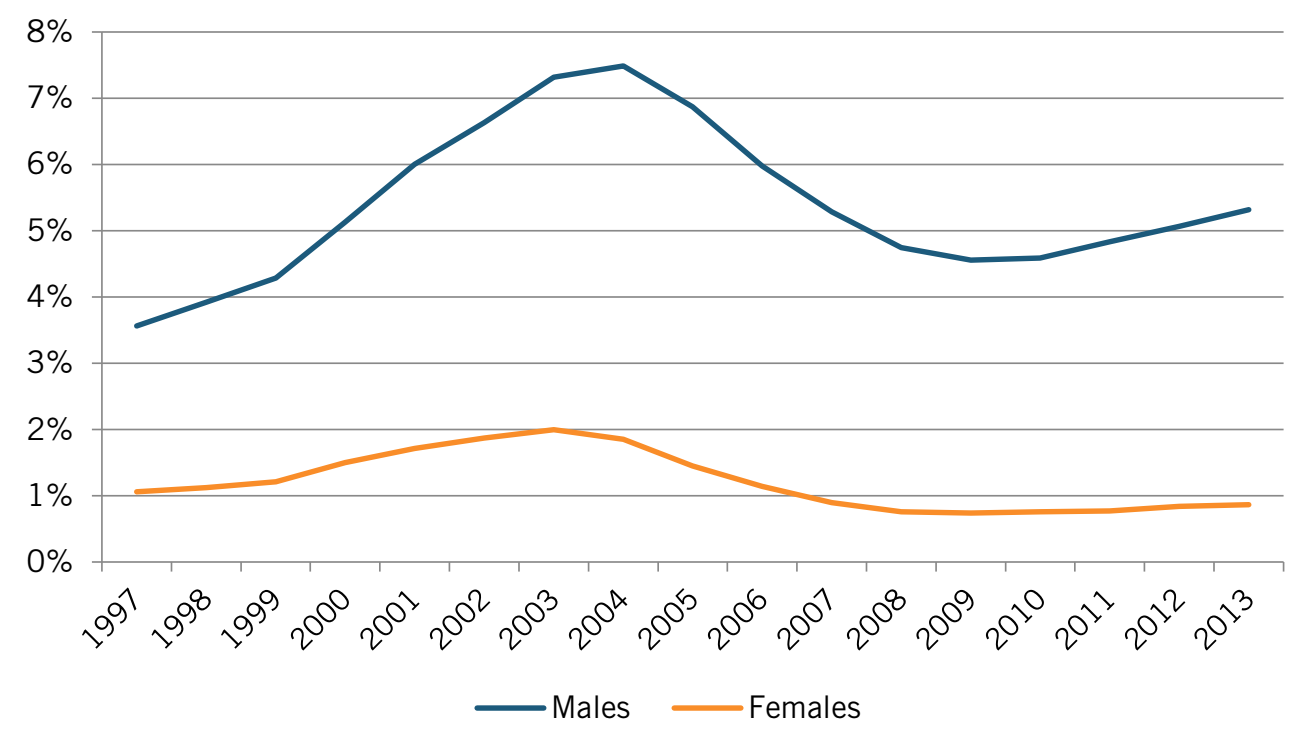

Figure 12: Advanced Degrees in Computer Science, 2001-2013 ${ }^{87}$

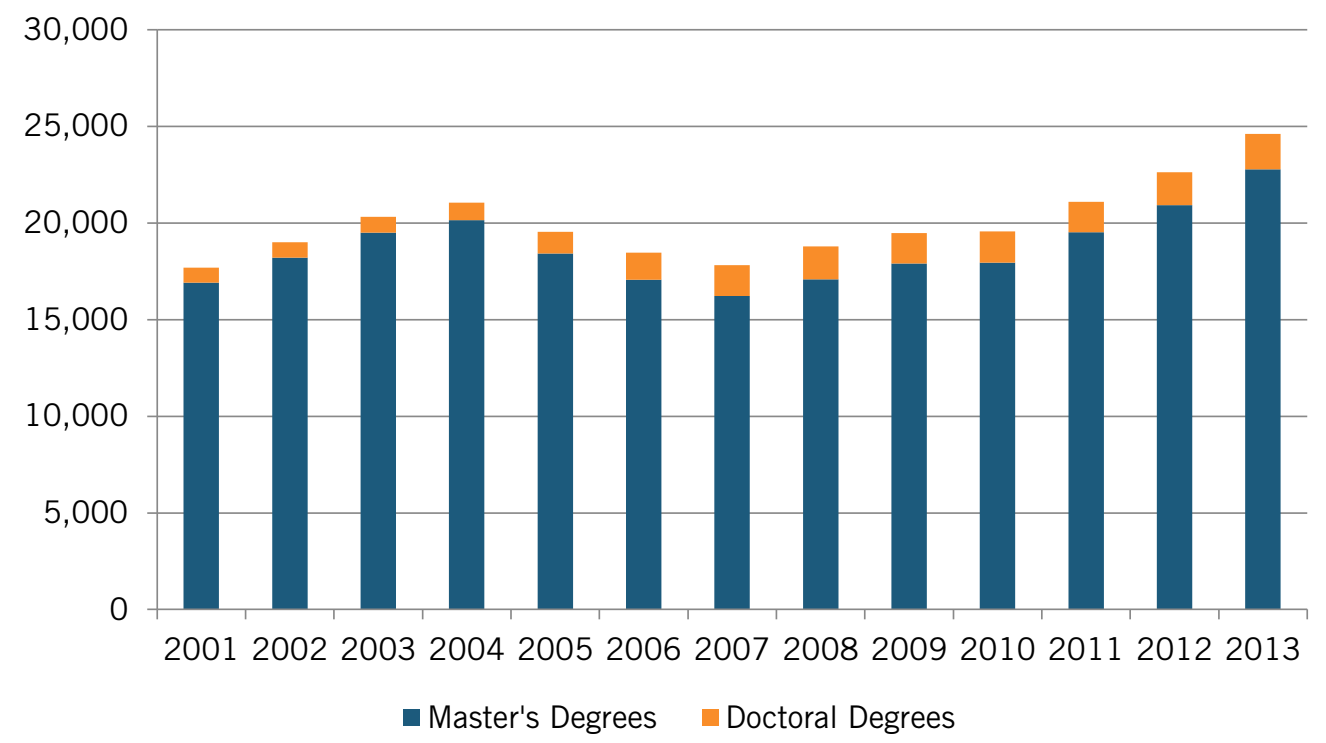

In addition to bachelors' degrees, U.S. universities also awarded 22,777 master's degrees and 1,826 doctoral degrees in CS. However, many of these degrees are earned by foreign students. In 2013, 52 percent of doctorate degrees and 43 percent of Masters degrees went to non-resident aliens, many of whom leave the country shortly after graduation, whether by choice or after failing to obtain a work visa. ${ }^{88}$ That foreign students wish to attend American universities is ultimately a positive for the United States. As Professor Giovanni Peri states, "The United States has the enormous international advantage of being able to attract talent in science, technology, and engineering from all over the world to its most prestigious institutions." ${ }^{89}$ However, the high proportion of foreign students demonstrates 
the comparative weakness of the U.S. educational system in preparing its own students to pursue advanced degrees in computer science.

While data are not available, all indications suggest that the upward trend has continued through 2014 and 2015. Student interest in introductory CS courses has seen rapid growth in many universities. At Stanford, MIT, the University of Pennsylvania, Harvard, and the University of Michigan, interest in introductory CS courses more than doubled between 2006 and $2013 . .^{90}$ At Northwestern University, the number of CS majors doubled and enrollment in introductory courses tripled in five years. ${ }^{91}$ At Harvard, 12 percent of undergraduates enrolled in the wildly popularity introductory course, CS50, in 2014, a roughly 500 percent increase from $2006 .{ }^{92}$

\section{Seeds of Growth}

This trend comes with important caveats. First, the increase is following an established pattern of cyclical growth and decline and may well be followed by a cyclical downturn. General excitement surrounding new computing technologies also plays a significant role in college enrollment. The supply of computer science graduates has had two brief spikesfirst in the mid-1980s and then again in the early to mid-2000s-corresponding with the advent of the personal computer and the dot-com boom respectively. We are witnessing another spike, with graduation rates growing steadily since a low in 2009. (See figure 10.) Exciting new technologies like smart phones and app development have drawn increased interest in computer science.

Conventional economic wisdom states that students should be drawn into computer science by higher wages. What is clear is that past and current spikes in interest in computer science are not created solely by wage expectations. For one thing, while wages have been increasing over the last decade, they have not shown any extreme growth nor changed compared to other majors. ${ }^{93}$ Computer science and engineering degrees offer the third-best return on investment of any major, and this has not changed. ${ }^{94}$

Wage incentives in IT occupations are not the only draw for student interest in computer science. Enrollment in computer science introductory courses is increasing as more and more non-majors realize that the subject is relevant to their fields. ${ }^{95}$ Moreover, computer science is shedding its "geeky" stigma. Some students, motivated by a desire to enact social change, do something good for the world, or become entrepreneurs, are turning to computer science.

\section{Artificial Capacity Limits}

While interest in computer science is increasing, colleges and universities are frequently unable to meet demand. Today's workforce demands expertise in computers and programming matched with knowledge in other fields. The increase of college majors has the unintended result of crowding out minors and other students looking to take just a few classes. Too few universities are willing and able to increase the computer science faculty and offer more classes to students; thus, not only will some students wanting to major in computer science lack the opportunity to do so, others, interested in exploring CS will also 
Universities commonly make it harder for students to study computer science than other subjects-the exact opposite of what society and the economy need. be disappointed. As Ed Lazowska states, "We're turning away many students we'd love to have. That's the tragedy." ${ }^{6}$ There are many students who could and would major in computer science in college if the bottlenecks were removed. Indeed, universities commonly make it harder for students to study computer science than other subjects- the exact opposite of what society and the economy need. Getting more kids engaged in science at the K-12 level will not solve the problem if CS programs at the tertiary level cannot be scaled up.

Most research on this topic has focused on high-profile universities such as elite private schools and large public universities. However, research suggests that the CS capacity problem extends to, and indeed may be more severe in, less renowned institutions. Smaller colleges, state universities serving localized areas, and community colleges may have an even harder time expanding offerings, hampered by both more limited budgets, in general, and less developed CS departments. For the highly ranked universities discussed above, increasing capacity is largely an exercise in scaling up existing programs. Less prestigious institutions may need to create course offerings from scratch. ${ }^{97}$

There are two main reasons why most colleges and universities have not expanded CS curricula adequately in response to growing demand. First, computer science, like most STEM-concentrated degrees, costs more for schools to provide than majors in the liberal arts or social sciences. Universities, particularly state schools that have faced funding cuts from state legislatures, are loath to take on these additional costs by encouraging or enabling more students to take courses. ${ }^{98}$ Better to have students major in English literature.

Second, universities and colleges often face resistance from within when they try to increase the size and offerings of departments, especially if such efforts are not accompanied by additional students for the university. Expanding the number of classes offered to match increasing demand is difficult for most universities, especially those with limited resources for increasing the faculty. In many cases, hiring faculty to address growing demand requires cutting faculty from other departments. Universities are naturally hesitant to do so, or unable to in the case of tenured faculty in other fields. The result is an educational system that responds slowly to student demand. Even schools with hefty endowments have trouble responding to student course priorities with faculty hires. Yale University, whose computer science faculty count has not grown from the 1980s, is finally hiring new professors in response to student petitions. ${ }^{99}$

If universities do not have strong incentives to divert and expend resources on computer science, progress will not be made. As Paul Romer argued in 2000, "The picture that emerges from this evidence is one dominated by undergraduate institutions that are a critical bottleneck in the training of scientists and engineers, and by graduate schools that produce people trained only for employment in academic institutions as a side effect of the production of basic research results." ${ }^{100}$ While Romer was writing during the previous upswing in computer science growth during the tech bubble, unfortunately the situation he 
Many universities, even those with top programs, acknowledge that they purposely cap numbers of CS majors when demand exceeds supply. observed still describes CS today. In short, while a computer science major may be better both for the student and the economy, some universities and colleges are largely indifferent to what majors its graduates have chosen. In this case, there is a tension between the interests of the universities and the interests of society.

Schools facing these tradeoffs have three options. First, they can place barriers and restrictions on entry into computer science classes or into the CS major or minor. Second, they can charge more for CS classes, decreasing demand for CS and using extra funds to increase the supply of opportunities in the CS department. Finally, schools can work in other ways to expand their offerings in CS to meet student demand.

\section{Barriers to studying CS}

Unfortunately, many schools facing increased demand for computer science are turning to the same stop-gap measure employed in the last spike during the early 2000s, chiefly 1) restricting the size of the major; 2) excluding or discouraging non-majors from taking advanced classes; 3) reducing course diversity and concentrating on introductory courses; 4) relying on MOOCs to teach introductory courses; or 5) having enormous class sizes in which students must sink or swim on their own. ${ }^{101}$

Many schools simply reject a higher percentage of CS applications rather than expand the slots available. In the California University system, admissions criteria for computer science are now higher than for other majors in order to limit the number of students enrolled. ${ }^{102}$ Similarly, data published by Carnegie Mellon University show that admission rates into computer science programs are only 5 percent, compared to 27 percent among the humanities. ${ }^{103}$ The admissions bottleneck also extend to Masters and Ph.D. programs, where admission rates among qualified applicants are low despite wage rates for graduates being very high. ${ }^{104}$

Others have limited demand by restricting students from switching into CS majors. For instance, at the University of California at Berkeley, students who did not initially apply for admission to the engineering school must have an GPA of 3.3 in three introductory courses in order to be eligible to declare a CS major. As this is a difficult feat (the average grade in each course is around a B, or a 3.0), students may not wish to risk falling short of the cutoff. ${ }^{105}$

While there are notable exceptions to this practice, many universities, even those with top programs, acknowledge that they purposely cap numbers of CS majors when demand exceeds supply. ${ }^{106}$ This deleterious practice limits the impact of wage incentives on producing computer science graduates and it substantially limits the number of students with multidisciplinary educations that include computer science. These frictions and barriers explain why high wages fail to result in increased graduation rates.

In cases where universities expand enrollment but not faculty, class sizes grow larger, faculty can spend less time per student and often introduction courses become "weed-out" courses with overly strict standards, leading to high rates of failed or discouraged students. 
The students who succeed, and the ones admitted into the program in the first place, tend to be students who have had prior computer experience (and even not all of these get in). Moreover, such prior experience is a poor predictor of future performance. ${ }^{107}$

As barriers to computer science are erected, the students impacted the most are underrepresented women and minorities. These groups are less likely to have had exposure to computer science in high school. Caps and weed-out classes often exacerbate existing gender and racial disparities in CS classrooms.

Students interested in taking a few classes or even minoring are also discouraged, as scarce departmental resources are dedicated to the majors who manage to survive weed-out introduction classes. The result is that it is harder to produce the "double-deeps" the digital economy needs - students with some CS skills complemented by another specialty (e.g., accounting, design, etc.).

\section{Raising the cost of CS}

Some universities are more transparent about this problem than others. In fact, many schools have taken to charging students more for computer science courses, using the increased tuition to expand their programs. For instance, the University of Maryland College Park, after seeing the number of computer science majors rise by 140 percent since 2009 , is instituting a differential price model and charging computer science majors, along with engineering and business majors, \$5,600 more than their classmates for a four-year degree. ${ }^{108}$ In essence, this has two effects, one on the supply side and one on the demand. First, it enables the university to expand and improve its offerings in these subjects, although still not enough to meet legitimate demand. The University of Maryland plans on using increased tuition to hire 23 more professors, introduce new minors, and increase financial aid. ${ }^{109}$ Second, it leads some students who otherwise would major in CS, especially those who are financially disadvantaged, to turn to other fields.

The problem with this strategy, reflecting the different needs of universities and societies, is that it sends exactly the wrong market signal. The most valuable degrees from a societal and economic perspective are now more expensive, while the less valuable ones are cheaper and more heavily subsidized. A better solution would be to raise tuition overall and dedicate the increased resources to expanding CS (and other STEM) faculty and resources.

And the ideal way to better align educational policy with societal needs would be to charge lower tuition rates for STEM classes. This is what Florida governor Rick Scott proposed in 2012 for students studying subjects deemed to be in demand among Floridian employers, including computer science. The initiative, never enacted, reasoned that freezing tuition rates for certain majors could incentivize students to pursue educations that will be valuable in the state's economy. ${ }^{110}$ However, unless steps are also taken to increase the classroom spots available for these students, this kind of proposal is unlikely to have much of an impact. 


\section{Examples of CS Expansion}

However, some schools are using resources to expand their CS offerings and accessibility. Some of these are coming from partnerships with technology companies. Harvard expanded its very popular computer science offerings after receiving a matching grant from Steve Ballmer, Microsoft's former CEO, enabling them to hire 12 new teachers in $2014 .{ }^{111}$ In 2015, Google awarded six CS Capacity grants to eight universities with three-year proposals to implement "innovative, inclusive, and sustainable approaches to address current scaling issues in university CS educational programs."

Recipient universities Carnegie Mellon, Duke, Mount Holyoke, George Mason, Rutgers, the University of California, Berkeley, North Carolina State, and UNC Chapel Hill have all begun to implement programs designed to improve enrollment and retention rates through innovative teaching methods such as peer-to-peer tutoring, separation of practice and assessments, mentoring, and the use of new technology tools to give students practice on concepts as they master them. ${ }^{12}$ Preliminary results show that these institutions have been able to increase the number of students entering and passing CS courses.

Stanford University has pledged not to cap computer science courses, citing a historical commitment to provide whatever classes students demand. Currently, 95 percent of Stanford undergraduates take at least one computer science class, and computer science has become the most popular major among women on campus; women now represent 30 percent of CS majors. ${ }^{113}$

At the graduate level, Georgia Institute of Technology (Georgia Tech) is breaking ground with a new online Masters of Science in Computer Science (OMSCS) degree. The program began in the Spring of 2014 and one year later had an enrollment of 2,300 students. In a few years, it could expand to enroll as many as 10,000 master's students. The entire online program costs only $\$ 6,600 .{ }^{114}$ Costs are cut down by relying on MOOCs to reach students from all over the world. MOOCs degrees like Georgia Tech's may be keys to providing the quantity of graduate level education demanded by students. However, Georgia Tech's degree so far has predominantly served demographics with high levels of access. Almost 90 percent of OMSCS program are male, compared to 76 percent of on-campus students. And while Asian students represent the majority of on-campus master's students, online students are likely to be white. ${ }^{115}$

\section{SUSTAINING AND FUELING PROGRESS}

In the past, upswings in interest have been cyclical in nature, driven by exciting new technologies that draw students into courses. There is no way of knowing whether recent increases will reach a zenith and then decrease, stay stable, or continue to grow.

There are positive signs. Businesses and advocacy organizations are increasingly lobbying state education systems to improve computer science standards, certify more teachers with the skills to impart real computer science skills, and allow students to count computer science as a math or science credit for graduation. Advocacy work has complemented increased interest in the field by students, much of it motivated by recent technology 
To successfully address the U.S. skills gap in computing, interest in the field must be matched by innovative education policy. advancements and the app economy. And the growth in student enrollment in computer science courses is unprecedented.

However, even this upswing in interest may not be enough to meet the demands of the U.S. workforce for hires with CS expertise and for those with CS competency and exposure. To successfully address the U.S. skills gap in computing, interest in the field must be matched by innovative education policy.

Interest in computer science needs to be complemented by high schools choosing to teach the subject, effectively trained and selected teachers, and curricula honed to emphasize rigorous studies rather than basic computing literacy. In addition, universities need to expand their offerings in computer science, increase the share of applicants accepted and emphasize retention of students majoring in CS, as well as allow non-majors to take CS at the college level. This movement will require the cooperation and coordination of all levels of the U.S. education system, local, state and federal government involvement, and continued contributions and expertise from industry and non-governmental organizations (NGOs).

There are a finite number of students with both the interest and the talent to excel in computing and pursue high-paying computing careers. Computer science education policy in the United States should focus on enabling a higher percentage of those students to acquire an in-depth education in computer science.

\section{Non-Traditional Initiatives}

While the American school system has not fully responded to the increased importance of computer science and IT skills, more employers, parents, and even students recognize the benefits of learning computer science. A new generation of non-profits and advocacy groups, learning-programs, and courses have sprung up in response. Non-profits such as Code Academy, CS10k, Black Girls Code, and Girls who Code seek to democratize access to computer science education across gender lines and socioeconomic divides, introduce computer science to students at a younger age, train more teachers, and put computer science into more schools. Some of these organizations are relative newcomers. Others have been working in the space well before the sudden recent growth in computer science, laying groundwork by establishing standards for computer science and generating interest in increasing the profile of the subject.

Perhaps none have had as large an impact as Code.org. Through its Hour of Code initiative, the organization has introduced tens of millions of children to coding and computer science, with 244 million hours of code logged on Code.org curriculum. The coursework has a focus on promoting inclusion of female and minority students. ${ }^{116}$ The organization has extensive teacher training programs, and has successfully lobbied for policy reform to allow CS to count as a graduation requirement in 17 states. ${ }^{117}$ By creating enormous exposure to CS in primary schools, pressure is placed on secondary and tertiary educators to provide CS courses to sate the academic appetite of students inspired by Code.org modules at an early age. By training teachers and pushing for state level reforms, 
Israel has 16.2 times as many students take rigorous computer science classes in high schools as the United States does on a per capita basis.
Code.org has also helped lay groundwork for secondary schools to meet that growing demand.

As non-profits, these are initiatives mostly funded through a combination of grants from private foundations, gifts from individuals, and corporate philanthropy. In particular, corporate philanthropy plays a major role in funding these efforts. Google partners with organizations all across the world, including the Boys and Girls Clubs of America, to provide computer science opportunities for youth through its CS First program and has provided grants to help improve capacity in universities through its CS Capacity program. Microsoft recently dedicated $\$ 75$ million to funding non-profit computer science education efforts, and several other large corporations have demonstrated commitments to providing funds to connect students with high-quality computer science and STEM education programs. Moreover, companies have rallied behind President Obama's "Computer Science for All" proposal, with Apple, Facebook, Microsoft, Oracle and Qualcomm, among others, pledging to support the initiative. Oracle, in fact, has pledged $\$ 200$ million in philanthropic spending to support the President's proposal if enacted. ${ }^{118}$ Moreover, an open letter to lawmakers signed by 27 state governors emphasized the need for federal involvement in CS education and called for expanding CS opportunities. ${ }^{119}$

In addition, computer learning programs aimed at adults are increasingly popular. Many Americans are realizing that further education courses in computing can complement their current skill-set and improve their career prospects. The recent TechHire Initiative, launched by the Obama administration in March of 2015, is investing $\$ 100$ million to train or retrain professionals in digital skills. Private initiatives like Recurse Center and others also provide continued computer science education allowing people to boost their digital skills. As workers are increasingly advantaged by having "double-deep" skills, or complementary expertise in both digital skills and in another field, many may seek to take basic courses to endow themselves with the CS expertise they need to succeed. However, short immersive classes meant to teach marketable skills are no substitute for the years of academic courses needed to learn computer science.

\section{International Comparisons}

Computer science education is becoming more prevalent all around the developed world, and many countries have already made integrating computer science into classrooms a top educational priority.

Israel leads the world in computer science education. The country was an early proponent of CS in high schools: it simultaneously expanded access to CS, improved the curriculum, trained teachers, and increased enrollment in universities 20 years ago, and reformed its curriculum in the late 1990s. On a per-capita basis, Israel has 16.2 times as many students as the United States taking rigorous computer science in high school. ${ }^{120}$ Its groundbreaking curriculum emphasized making CS a science instead of teaching only coding. Students should be taught programming, proponents argue, as a means to reinforce deeper and more important knowledge in creating and understanding algorithms, and to create a subject 
that would be as respected by tertiary institutions as traditional biology, chemistry, and physics courses. ${ }^{121}$ The students studying under this curriculum in recent years have helped transform Israel into a major player in technology innovation, with Tel Aviv emerging as a hub for technology. No other country has taken such an intentional, coordinated effort to improve CS education. As in the United States, Israeli undergraduate enrollment in computer science peaked in the early 2000s and has yet to fully recover from that high. However, with 5.7 percent of undergraduates majoring in computer science or mathematics, Israel still has a much higher concentration of CS majors than does the United States. ${ }^{122}$

Many other nations have also begun to reform their computer science curriculum with an eye towards success in global marketplace. Finland, Denmark, Australia, and Singapore have all taken real steps towards reforming CS education to enhance future competitiveness in high-tech sectors. ${ }^{123}$ These include introducing CS to primary school students, adding more deep concepts to curricula, and training more specialized teachers.

In 2013, the United Kingdom mandated that students aged 5 to 14 take computer science, and for all high school students to have the option to take the course. ${ }^{124}$ Through this measure, the United Kingdom hopes to be able to address their own impending technology-skills shortage, and help fill the estimated 249,000 tech-skilled jobs that will be available in the United Kingdom by $2020 .{ }^{125}$ However, though CS is now required, the $\mathrm{UK}$ is still struggling to train the computer science teachers needed to teach every primary student in the country.

\section{POLICY RECOMMENDATIONS}

Graduates with skills in computer science are a valuable resource for the U.S. economy. It is therefore not enough to rely on the "market" to determine the number of workers with computer science skills. If for no other reason, this is because key educational institutions involved do not adequately respond to market signals. As a result, it is incumbent on states and the federal government to require or incentivize secondary and tertiary education institutions to expand their ability to train a broader group of students in computer science. Expanding CS education, along with other STEM intensive training that is in high demand by the workforce such as engineering, should be considered to be an essential component of U.S. innovation policy. ${ }^{126}$

To close the gap with other nations and improve computer science education, the United States needs to take several steps to enable all segments of the computer science pipeline to grow. The most important step is to leverage current momentum in the field.

\section{Allow computer science to count}

At the high school level, all states should allow CS to count for a math or science graduation requirement, removing barriers to students choosing whether or not to take computer science courses. This also allows students to take CS earlier in high school instead of waiting until all their graduation requirements have been met. Students who 
have an aptitude for science, regardless of race or gender, are more likely to take CS courses if they count towards graduation.

\section{Teach computer science in all high schools}

States should prioritize making computer science available in every school. Several state and local governments, including Chicago and New York City, have begun to answer the call by mandating full access to computer science in their schools. Similarly, Texas required CS in schools, though implementation of this has been slow. In 2015, Arkansas passed a measure to put CS in all schools after Asa Hutchinson made CS education a core focus of his gubernatorial campaign. ${ }^{127}$ The state plans on having all primary students take CS by the 2017 -2018 school year, with CS available at every high school. In addition, Idaho, Alabama, Utah, and Washington have prioritized CS education, and are actively working to improve curriculum and expand access. Virginia is now in the process of passing legislation that will make it the first state to make CS a core academic requirement for all K-12 students. ${ }^{128}$ However, these mandates are only possible and advisable if quality, certified teachers are available. Otherwise, the result will likely be low-quality substitutes for real CS courses taught by teachers without computer expertise.

\section{Increase the number of qualified computer science teachers}

U.S. educational policy should focus on providing many more students with the opportunity to learn computer science in a rigorous manner from a certified teacher. All 50 states should have certification programs that allow education graduate students seeking to become teachers to specialize in computer science. Federal initiatives can help promote both the supply of certification programs and demand for these programs. The federal government should provide matching grants to states for establishing teacher certification programs in CS. Moreover, the federal government should provide funds to subsidize the cost of teacher certification and master's programs for prospective teachers who successfully teach computer science in the United States for five years.

States are loath to require teachers to be certified for fear of losing existing teachers. However, subsidizing the cost of certification and providing higher wages for teachers with certification will incentivize teachers to acquire certification without making it a requirement. Federal matching grants should also provide extra compensation for teachers with CS certification, for a fixed period of time, say 10 years. This funding would raise wages for CS teachers, which is essential to attract a greater number of teachers who could otherwise be earning more in the private sector.

Funding for these grants should come through the "Computer Science for All" plan, part of President Obama's recent budget, which proposes $\$ 4.1$ billion over 3 years to states for expanding CS education. ${ }^{129}$ Under this plan, states create comprehensive 5-year plans to expand their K-12 CS offerings, and all states with well-designed strategies would receive funds. The President's proposal also allots $\$ 100$ million to specific districts to target underrepresented populations and serve as scalable models for the rest of the country. ${ }^{130}$ Attracting and training teachers by following the above recommendations should be a cornerstone of states' plans for promoting CS education. This federal support will help 
Doubling the number of STEM high schools will allow more students with a passion and deep ability to excel in computer science. states invest in quality teachers and pay them higher wages, as well as to develop and implement better curricula and build on current successes in computer science. Congress should include these funding proposals in the 2017 fiscal budget.

\section{Double the number of STEM charter schools}

There are approximately 100 STEM-focused high schools in America. Most of these public STEM high schools can provide a deep-dive into computer science for interested students and have been proven to be effective in including minorities and students from socioeconomically disadvantaged areas in high-quality STEM education. ${ }^{131}$ Doubling the number of STEM high schools will allow more students with a passion and deep ability to excel in CS. Moreover, efforts should be made to ensure that all existing STEM-focused high schools provide a deep and rigorous curriculum in CS.

\section{Create incentives for more tertiary computer science}

At the university level, policymakers need to address the barriers that limit the number of students able to take computer science. To encourage higher CS enrollment and graduation rates, the National Science Foundation should provide grants to schools that have increased or are implementing programs to increase enrollment and retention in computer science. Schools seeking to expand course offerings, hire more faculty, and provide students in computer science with more resources to improve retention rates should be eligible to apply. These benefits should aim to incentivize universities and colleges to emulate the efforts of universities receiving Google's CS Capacity grants. ${ }^{132}$

The federal government should also require increased transparency as a prerequisite for certain educational funds. For instance, schools should be required to monitor and disclose the number of CS applicants, prospective majors, and their retention rates in CS subjects in order to be eligible for certain federal benefits. Ideally this would be done for all STEM disciplines.

States should also provide more funding to offset the higher costs of training CS majors. Because educating a CS major is more expensive than training an English literature major, for example, schools should receive higher levels of funding for graduating a CS major or a major in another relatively expensive STEM major than for lower cost majors. This will help correct the perverse incentives universities face to steer students towards lower cost majors.

Finally, to help address low gender and minority rates in CS, schools should focus more on potential, not on previous access to CS, when considering admission. Admission departments also tend to overemphasize experience over problem solving, leadership, and other intangible characteristics. ${ }^{133}$ Thus, the solution should be to change the gating mechanism for admissions. To address this problem, Carnegie Mellon University (CMU) successfully weighted prior experience lower in their ranks of preference for admission, and managed in 5 years to increase the enrollment rate of women in computer science majors from 7 percent in 1995 to 42 percent in $2000 .{ }^{134}$ 


\section{CONCLUSION}

Computer science education is increasingly important to students and the economy. Despite this, computer science is offered at only a small fraction of American schools, and then lack of unified standards and curricula that focus on skills rather than concepts erodes the value of these courses. While practically all students take biology, computer science is frequently allotted few resources or deemed to be an unimportant class, and gender and ethnicity play a large role in who takes computer science.

The outlook for computer science education, however, is improving. Spearheaded by nonprofit initiatives, the importance of coding has led to concerted efforts to increase the number of students taking CS courses, provide teachers with resources, and generate interest in the field. Public initiatives to give more students access to rigorous CS classes are beginning to make a difference. As a result, high school students taking CS, as well as college students interested in majoring in CS have risen dramatically. However, to maintain this upswing in interest and satisfy the economy's demand for computing skills, dedicated efforts must be made to recognize the true value of CS as a rigorous, relevant academic discipline, even prioritizing CS above other more established science courses. Universities must find ways to increase the number of computer science courses they offer to satisfy demand from students. And, action to introduce students to CS at an earlier age is key to teaching students the value of CS. 


\section{ENDNOTES}

1. Aamer Madhani, "Obama apologizes for joking about art history majors," USA Today, February 19, 2014, http://www.usatoday.com/story/theoval/2014/02/19/obama-apologizes-to-texas-art-historyprofessor/5609089/.

2. Bureau of Labor Statistics, Current Population Survey, (Median weekly earnings of full-time wage and salary workers by detailed occupation and sex, Household Data Annual Averages; Accessed March 30, 2015), http://www.bls.gov/cps/cpsaat39.htm.

3. This figure, presented at the TechHire rollout, has drawn critique in regards to its methodology. However, recent $\mathrm{H}-1 \mathrm{~B}$ petitions, support this, as does Change the Equation and Business Roundtable paper in which a few large companies reported 200,000 openings for STEM jobs. Change the Equation and Business Roundtable, "Survey on U.S. Workforce Skills: Summary of findings," December 3, 2014, http://changetheequation.org/sites/default/files/2014\%20BRT-

CTEq\%20Skills\%20Survey\%20Slides_0.pdf

4. Bureau of Labor Statistics, Current Population Survey, (Median weekly earnings of full-time wage and salary workers by detailed occupation and sex, Household Data Annual Averages; Accessed March 30, 2015), http://www.bls.gov/cps/cpsaat39.htm.

5. Bureau of Labor Statistics, Labor Force Statistics from the Current Population Survey (Computer and mathematical occupations, February 2015; accessed March 30, 2016),

http://www.bls.gov/web/empsit/cpseea30.htm; Change the Equation, "STEM Help Wanted," accessed March 30, 2016, http://changetheequation.org/stemdemand.

6. Change the Equation, "Off the Grid: The uncounted women in computing," accessed March, 30, 2015; http://changetheequation.org/sites/default/files/Offthegrid_infographic.pdf.

7. http://www.bls.gov/ooh/computer-and-information-technology/home.htm

8. Bureau of Labor Statistics, Occupational Employment and Wages (15-0000 Computer and Mathematical Occupations (Major Group), May 2015, employment; accessed April 13, 2016), http://www.bls.gov/oes/current/oes150000.htm\#ind; Jacob Funk Kirkegaard, "The Accelerating Decline In America's High-Skilled WorkForce: Implications for Immigration Policy” (Peterson Institute for International Economics, December 2007); http://www.piie.com/publications/briefs/kirkegaard4136.pdf.

9. Bureau of Labor Statistics, Occupational Outlook Handbook (computer and information technology occupations, 2012; accessed March 31, 2015), http://www.bls.gov/ooh/computer-andinformationtechnology/software-developers.htm\#tab-1z (author's calculation; removed math and stats jobs); "1,000,000 more job than students by 2020," Code.org, accessed April 1, 2015, http://code.org/images/cs-stats/more-jobs-than-students.png; "Solving the Diversity Dilemma, Changing the Face of the STEM Workforce" (Change the Equation, February 2015),

http://changetheequation.org/sites/default/files/2015\%20Solving\%20the\%20Diversity\%20Dilemma\%2 0FINAL\%206.2015.pdf; Adams B. Nager and Robert D. Atkinson, "Debunking the Top Ten Arguments Against High-Skilled Immigration” (Information Technology and Innovation Foundation, April 2015), https://itif.org/publications/2015/04/20/debunking-top-ten-arguments-against-high-skilledimmigration.

10. Bureau of Labor Statistics, Current Population Survey (Median weekly earnings of full-time wage and salary workers by detailed occupation and sex; accessed March 30, 2015), http://www.bls.gov/cps/tables.htm.

11. Ibid.

12. National Association of Colleges and Employers, Salary Survey: Top-Paid Majors for the Class of 2014; http://naceweb.org/s04162014/top-paid-majors-class-of-2014.aspx.

13. Tyler Soper, "Analysis: The exploding demand for computer science education, and why America needs to keep up," Geekwire, June 6, 2014, http://www.geekwire.com/2014/analysis-examining-computerscience-education-explosion/.

14. David Moschella, “The Emerging Double-Deep Economy," Leading Edge Forum, September 17, 2013, https://leadingedgeforum.com/publication/the-emerging-double-deep-economy-2318/.

15. Adams Nager, "Everybody needs STEM skills.” Innovation Files, December 22, 2014, http://www.innovationfiles.org/everybody-needs-stem-talent/.

16. “Make Computer Science in K-12 count!" Code.org, Computing in the Core, accessed January 11, 2016, https://code.org/files/convince_your_school_or_state.pdf; Steve Taylor, “Obama’s 'TechHire’ Follows 
Lead of Mission' EDC's 'Code the Town,” Rio Grande Guardian, March 22, 2015;

http://riograndeguardian.com/obama-takes-missions-code-the-town-nationwide/.

17. David Moschella, “Double-deep and How Its Forces Are Reshaping Today's Economy,” Leading Edge Forum, April 4, 2013; https://leadingedgeforum.com/publication/double-deep-and-how-its-forces-arereshaping-todays-economy-2294/

18. Harry Cheng, "Teaching math with computer programming can help narrow achievement gap," EdSource, April 26, 2016, http://edsource.org/2016/teaching-math-with-computer-programming-canhelp-narrow-achievement-gap/563371; Morten Brekke and Per Henrik Hogstad, "New teaching methods - Using computer technology in physics, mathematics and computer science," International Journal of Digital Society (IJDS), Volume 1, Issue 1, March 2010,

http://www.tlu.ee/ - tony/oppetoo/arvutustehnika_rakendusvara/New\%20teaching\%20methods\%20\%20Using\%20computer\%20technology\%20in\%20physics, \%20mathematics\%20and\%20computer\%20 science.pdf; Rhett Allain, "You Should Be Coding in Your Physics Course," Wired, August 14, 2015, http://www.wired.com/2015/08/coding-physics-course/.

19. Cynthia English, "Parents, Students Want Computer Science Education in School," Gallup, August 20, 2015, http://www.gallup.com/poll/184637/parents-students-computer-science-education-school.aspx.

20. Mark Guzdial, Learner-Centered Design of Computing Education: Research on Computing for Everyone, (Morgan \& Claypool, 2015).

21. "Computer Science Education Advocacy Toolkit" (Computer Science Teachers Association, 2009), http://www.csta.acm.org/Advocacy_Outreach/sub/Advocacy_Toolkit_Final_.pdf; Chris Stephenson et. al, "The New Educational Imperative: Improving High School Computer Science Education" (Computer Science Teachers Association Curriculum Improvement Task Force, February 2005), https://csta.acm.org/Communications/sub/DocsPresentationFiles/White_Paper07_06.pdf.

22. Bureau of Labor Statistics, Current Population Survey (median weekly earnings of full-time wage and salary workers by detailed occupation and sex; accessed March 30, 2015), http://www.bls.gov/cps/tables.htm.

23. National Science Foundation, Science and Engineering Indicators 2012, Higher Education in Science and Engineering (Appendix Table 2-19; accessed March 22, 2015), http://www.nsf.gov/statistics/seind12/c2/c2s2.htm.

24. Neil G. Ruiz, The Geography of Foreign Students in U.S. Higher Education: Origins and Destinations" (Brookings, August 2014), http://www.brookings.edu/research/interactives/2014/geography-of-foreignstudents\#/M10420.

25. Michael Finn, "Stay Rates of Foreign Doctorate Recipients from U.S. Universities, 2011” (Oak Ridge Institute for Science and Education, January 2014), http://orise.orau.gov/files/sep/stay-rates-foreigndoctorate-recipients-2011.pdf.

26. "The Impact of the H-1B Temporary Nonimmigrant Visa Program on Workers, Graduates, \& the U.S. Labor Market” (Jobs with Justice, Economic Policy Institute; November 2013), http://guestworkerdata.org/wp-content/uploads/2014/02/H1BNationalFactsheet11_13_13FINAL.pdf.

27. Nager and Atkinson, "Debunking;" Robert D. Atkinson and Luke A. Stewart, "The Real Story on Guestworkers in the High-skill U.S. Labor Market" (Information Technology and Innovation Foundation, May 2013), http://www2.itif.org/2013-guestworkers-high-skill-labor-market.pdf.

28. Department of Labor, Office of Foreign Labor Certification, OFLC Performance Data (LCA programs, FY 2014; accessed March 30, 2015), http://www.foreignlaborcert.doleta.gov/performancedata.cfm; Bureau of Labor Statistics, Occupational Employment Statistics (national employment, 2014; accessed March 30, 2015), http://www.bls.gov/oes/tables.htm. Author's analysis. Occupations considered computer-related include: Computer and Information Research Scientists; Computer and Information Systems Managers; Computer Occupations, all other; Computer Programmers; Computer Support Specialists; Computer Systems Analysts; Database Administrators; Information Security Analysts; Network and Computer Systems Administrators; Web Developers; Software developers, applications and systems software.

29. Ibid.

30. Matt Graham and Lazaro Zamora, "H-1B Visa Cap Expected to Be Hit Within Days-Again," Bipartisan Policy Center, April 1, 2014, http://bipartisanpolicy.org/blog/h-1b-visa-cap-expected-be-hitwithin-days/; U.S. Citizenship and Immigration Services, "USCIS Runs Random Selection Process for H-1Bs, Revised Business Procedures Expedite Processing," news release, April 13, 2007, http://www.uscis.gov/sites/default/files/files/pressrelease/H1Bfy08CapUpdate041307.pdf; Kumar, "H1B 
Visa Cap Reach Dates History 2000 to 2017," March 5, 2016, http://redbus2us.com/h1b-visa-capreach-dates-history-2000-to-2014-graph-uscis-data/; U.S. Citizenship and Immigration Services, "USCIS Reaches FY 2017 H-1B Cap," press release, April 7, 2016, https://www.uscis.gov/news/newsreleases/uscis-reaches-fy-2017-h-1b-cap.

31. Megan Smith, Jeffrey Zients, "President Obama Launches TechHire," The White House Blog, March, 10, 2015, https:/www.whitehouse.gov/blog/2015/03/10/president-obama-launches-techhire.

32. Carl Straumsheim, "The First Cohort: AT\&T employees, men and domestic students dominate the first cohort of Georgia Tech's new fully online master's degree program," Inside Higher Ed, December 13, 2013, https://www.insidehighered.com/news/2013/12/13/georgia-tech-admits-first-cohort-ahead-onlinemasters-degree-program-launch.

33. Claudia Goldin and Lawrence F. Katz, "Mass Secondary Schooling and the State: The Role of State Compulsion in the High School Movement," National Bureau of Economic Research, 2011, http://www.nber.org/chapters/c12002.pdf.

34. Carolyn Dimitri, Anne Effland, and Neilson Conklin, "The 20th Century Transformation of U.S. Agriculture and Farm Policy" (United States Department of Agriculture Economic Research Service, 2005),

http://www.ilovefarmers.org/downloads/The20thCenturyTransformationofU.S.AgricultureandFarmPolic y.pdf.

35. José Vázquez, "High School Biology Today: What the Committee of Ten Did Not Anticipate," CBE Life Sci Educ. 2006 Spring; 5(1): 29-33, http://www.ncbi.nlm.nih.gov/pmc/articles/PMC1635139/\#ref8.

36. William Wood, “Advanced High School Biology in an Era of Rapid Change: A Summary of the Biology Panel Report from the NRC Committee on Programs for Advanced Study of Mathematics and Science in American High Schools," Cell Biol Educ. 2002 Winter; 1: 123-127, http://www.ncbi.nlm.nih.gov/pmc/articles/PMC149809/\#B8.

37. National Center for Educational Statistics, Digest of Educational Statistics (Table 225.40, 2009; accessed January 4, 2016); https://nces.ed.gov/programs/digest/d13/tables/dt13_225.40.asp.

38. Modern math education revolves principally around coursework leading up to calculus. Students typically take algebra, geometry, Algebra II, and pre-calculus. A rapidly growing percentage of students now manage to reach Calculus, or even Calculus II in high school, as reflected by growing numbers of AP tests in these subjects. [Data] While calculus is important for college bound individuals, statistics may be a more useful subject for students not pursuing college courses.

39. Wood, "High School Biology Today."

40. National Center for Educational Statistics, Digest of Educational Statistics (Table 225.40: Percentage of public and private high school graduates taking selected mathematics and science courses in high school, by selected student and school characteristics: Selected years, 1990 through 2009; Accessed January 11, 2016); https://nces.ed.gov/programs/digest/d13/tables/dt13_225.40.asp.

41. "A Nation at Risk" (U.S. Department of Education, April 1983), http://www2.ed.gov/pubs/NatAtRisk/risk.html; Constance Holden, "Wanted: 675,000 Future Scientists and Engineers," Science, June 30, 1989, 1536-1537; Hearing on Shortage of Engineers and Scientists, Before the Senate Committee on Commerce, Science and Transportation, Subcommittee on Science, Technology, and Space (statement of Erich Bloch, director, National Science Foundation) (May 8, 1990), 25.

42. National Commission on Excellence in Education, A Nation at Risk: The Imperative for Educational Reform (Washington, DC, 1983).

43. Cameron Wilson et al., "Running On Empty: The Failure to Teach K-12 Computer Science in the Digital Age" (Association for Computing Technology and the Computer Science Teachers Association, 2010), http://runningonempty.acm.org/roemap.html.

44. Phillip Reese, "Coding courses a rarity in California high schools despite tech explosion," Sacramento Bee, March 19, 2016, http://www.sacbee.com/news/local/education/article67095957.html.

45. O*Net Online, Summary Report for Potters, manufacturing, accessed April 20, 2016, http://www.onetonline.org/link/summary/51-9195.05.

46. O*Net Online, Summary Report for Computer Systems Analysts, accessed April 20, 2016, http://www.onetonline.org/link/summary/15-1121.00.

47. National Center for Educational Statistics, "America's High School Graduates: Results of the NAEP High School Transcript Study” (2011), http://nces.ed.gov/nationsreportcard/pdf/studies/2011462.pdf. 
48. College Board, AP Course Audit (Computer Science and Calculus, 2013-2014, United States; accessed April 27, 2015), https://apcourseaudit.epiconline.org/ledger/search.php; http://www2.itif.org/2013guestworkers-high-skill-labor-market.pdf

49. Chris Stephenson, "The New Educational Imperative: Improving High School Computer Science" (Computer Science Teachers Association, February, 2007), http://www.csta.acm.org/Communications/sub/DocsPresentationFiles/TCEAPres07.pdf.

50. College Board, AP Program Participation and Performance Data (National Report, 2015; Accessed January 12, 2016), http://research.collegeboard.org/programs/ap/data/participation/ap-2015.

51. AP Data, Archived Data 2014 (AP Program Size and Increments, 1990-2014; accessed March 10, 2016), http://research.collegeboard.org/programs/ap/data/archived/ap-2014; "AP* Computer Science: A Brief History," accessed April 1, 2016,

52. "A Framework for K-12 Computer Science Education," k12cs website, accessed May 11, 2016, https://k12cs.org/.

53. “State-by-State Results,” Running on Empty, 2010, accessed January 21, 2016, http://runningonempty.acm.org/roemap.html.

54. Simon Peyton Jones, "Computing at School: International comparisons" (Microsoft Research UK, November 2011), http://www.computingatschool.org.uk/data/uploads/internationalcomparisons-v5.pdf.

55. College Board, AP Program Participation and Performance Data (AP Exams Volume Changes, 20032013, 2005-2015; accessed January 12, 2016), http://research.collegeboard.org/programs/ap/data/participation/ap-2015; AP Data, Archived Data 2014 (AP Program Size and Increments, 1990-2014; accessed March 10, 2016), http://research.collegeboard.org/programs/ap/data/archived/ap-2014; "AP* Computer Science: A Brief History," accessed April 1, 2016, http://www.apsi.thecubscientist.com/05_DailySchedule/historyAPCS.pdf.

56. “AP Computer Science Principles," Advances in AP, accessed January 12, 2016, https://advancesinap.collegeboard.org/stem/computer-science-principles.

57. Ibid.

58. College Board, AP Program Participation and Performance Data (National Report, 2015; Accessed January 12, 2016), http://research.collegeboard.org/programs/ap/data/participation/ap-2015.

59. Bureau of Labor Statistics, Labor Force Statistics from the Current Population Survey (Median weekly earnings of full-time wage and salary workers by detailed occupation and sex, 2014; accessed January 12, 2016), http://www.bls.gov/cps/cpsaat39.htm.

60. "Women Who Choose Computer Science-What Really Matters: The Critical Role of Encouragement and Exposure" (Google, May 2014), https://docs.google.com/file/d/0BE2rcvhnlQ_a1Q4VUxWQ2dtTHM/edit.

61. Hadi Partovi, "Computer science: the impact of K-12 on university enrollment," Code.org, April 18, 2016, http://blog.code.org/post/143007230537/computer-science-the-impact-of-k-12-on-university.

62. College Board, AP Program Participation and Performance Data.

63. College Board, AP Program Participation and Performance Data (National Report, 2015; Accessed January 12, 2016), http://research.collegeboard.org/programs/ap/data/participation/ap-2015.

64. College Board, AP Program Participation and Performance Data.

65. Ibid.

66. Ibid.

67. Ibid.

68. "Where Computer Science Counts," Code.org website, accessed March 9, 2016, https://code.org/action.

69. “State-by-State Results,” Running on Empty, 2010, accessed January 21, 2016, http://runningonempty.acm.org/roemap.html.

70. Computer Science Teachers Association, "CSTA National Secondary School Computer Science Survey," accessed March 28, 2016, http://csta.acm.org/Research/sub/Projects/ResearchFiles/CSTASurvey13Results.pdf; question 19.

71. Chris Stephenson and Patricia Phillips, "Bugs in the System: Computer Science Teacher Certification in the U.S.” (Computer Science Teachers Association and the Association for Computing Machinery, 2013) https://csta.acm.org/ComputerScienceTeacherCertification/sub/CSTA_BugsInTheSystem.pdf.

72. Reese, "Coding courses a rarity in California high schools despite tech explosion;" CSTA survey; "CSTAOracle Academy 2014 U.S. High School CS Survey: The State of Computer Science in U.S. High 
Schools: an Administrator's Perspective," Computer Science Teachers Association, http://csta.acm.org/Research/sub/Projects/OracleSurvey_DataSummary.pdf.

73. College Board, AP - Archived Data (2006-2014, State reports), http://research.collegeboard.org/programs/ap/data/archived.

74. Chris Kardish, "Does Raising High School Grad Requirements Work?” Governing, August 6, 2014, http://www.governing.com/topics/education/gov-does-raising-high-school-grad-requirements-translateto-higher-achievement.html; Education Commission of the States, "Individual State Profile: Standard High School Graduation Requirements," accessed April 27, 2016, http://ecs.force.com/mbdata/mbprofall?Rep=HS01.

75. Jessica Leber, "Want to get Girls and Minorities Into Coding? Stop Making Computer Science an Elective," Co.Exist, December 12, 2013, http://www.fastcoexist.com/3023167/want-to-get-girls-andminorities-into-coding-stop-making-computer-science-an-elective.

76. Karen Waters, "Three in four voters believe computer science should count as a math or science credit," (Washington STEM, February 2013), http://www.washingtonstem.org/News-Media/Press-

Releases/Statewide-STEM-Poll-Feb-2013\#.VTZcuPnF-Ck.

77. Code.org website, accessed March 28, 2016, https://code.org/about.

78. Alfred Thompson, "So you want to teach computer science," Microsoft Blog, June 8, 2012; https://blogs.msdn.microsoft.com/alfredth/2012/06/08/so-you-want-to-teach-computer-science/; Kathi Fisher, "Can Math Teachers Teach Computer Science?” news release, Worcester Polytechnic Institute, October 9, 2015, https://www.wpi.edu/news/20156/mathcsci.html. "Bugs in the System" (CSTA, ACM, 2013).

79. "CSTA-Oracle Academy 2014 U.S. High School CS Survey: The State of Computer Science in U.S. High Schools: an Administrator's Perspective," Computer Science Teachers Association, http://csta.acm.org/Research/sub/Projects/OracleSurvey_DataSummary.pdf.

80. Chris Stephenson, "The Thorny Issue of CS Teacher Certification," Google Research Blog, July 16, 2015, http://googleresearch.blogspot.com/2015/07/the-thorny-issue-of-cs-teacher.html.

81. CS10K website, accessed March 29, 2016, https://cs10kcommunity.org/.

82. National Center for Education Statistics, Digest of Educational Statistics, (Table 325.35. Degrees in computer and information sciences conferred by postsecondary institutions, by level of degree and sex of student: 1970-71 through 2012-13; accessed March 25, 2016), http://nces.ed.gov/programs/digest/2014menu_tables.asp.

83. Only 20 percent thought they had an idea, and of those 50 percent answered programming. Other common answers included advanced computer use, repair, networking, how computers work, and "Computer Stuff." Right answers included software programming, hardward design, problem solving using computers, using computers in other fields, etc; "Women Who Choose Computer Science-What Really Matters: The Critical Role of Encouragement and Exposure,” (Google, May 2014), https://docs.google.com/file/d/0B-E2rcvhnlQ_a1Q4VUxWQ2dtTHM/edit.

84. Krista D. Mattern, Emily J. Shaw, and Maureen Ewing, College Board, "Is AP Exam Participation and Performance Related to Choice of College Major?” (College Board, 2011), http://professionals.collegeboard.com/profdownload/pdf/RR2011-6.pdf; Google, Survey Results of U.S. Employees (2010) (unpublished); "Computer Science in Public Schools," Exploring CS, accessed April 3, 2016; http://www.exploringcs.org/resources/cs-statistics.

85. National Center for Education Statistics, Digest of Educational Statistics, (Table 325.35. Degrees in computer and information sciences conferred by postsecondary institutions, by level of degree and sex of student: 1970-71 through 2012-13; accessed March 25, 2016), http://nces.ed.gov/programs/digest/2014menu_tables.asp.

86. National Center for Educational Statistics, Digest of Educational Statistics (Table 322.20, Table 325.35; accessed June 1, 2015), http://nces.ed.gov/programs/digest/2014menu_tables.asp.

87. National Center for Educational Statistics, Digest of Educational Statistics (Table 323.10; Accessed March 20, 2016), http://nces.ed.gov/programs/diges/d14/tables/dt14_324.10.asp; 2002 data is Author's estimate.

88. National Center for Educational Statistics, Digest of Educational Statistics (Table 323.40, Table 324.25; Accessed March 20, 2016), http://nces.ed.gov/programs/digest/d14/tables/dt14_323.40.asp. Nager, Atkinson, "Debunking."

89. Stuart Anderson, "International Students Are Vital to U.S. Higher Education,” International Educator, May 2014, http://www.nafsa.org/_/File/_/ie_mayjun14_frontlines.pdf. 
90. Soper, "The exploding demand for computer science education."

91. Emily Ayshford, “Computer Science Everywhere,” McCormick, Northwestern Enginering, Fall 2013, http://www.mccormick.northwestern.edu/magazine/fall-2013/computer-science-everywhere.html.

92. Meg Bernhard, "CS50 Logs Record-Breaking Enrollment Numbers," The Harvard Crimson, September 11, 2014, http://www.thecrimson.com/article/2014/9/11/cs50-breaks-enrollment-records/?page=1; Soper, "The exploding demand for computer science education."

93. Nager, Atkinson, "Debunking."

94. Robert Litan, "A lesson from the decline in computer-related majors," Brookings, March 23. 2015, http://www.brookings.edu/research/opinions/2015/03/23-decline-computer-majors-litan; "It depends what you study, not where," The Economist, March 12, 2015, http://www.economist.com/news/unitedstates/21646220-it-depends-what-you-study-not-where.

95. Tyler Soper, "Analysis: The exploding demand for computer science education, and why America needs to keep up,” Geekwire, June 6, 2014, http://www.geekwire.com/2014/analysis-examining-computerscience-education-explosion/.

96. Soper, "The exploding demand for computer science education."

97. Conversation with Chris Stephenson, April 8, 2016.

98. Lazowska, Roberts, and Kurose, "Tsunami or Sea Change."

99. John Lauerman, "Yale Stepping Up Computer Science After Students Demand Better Tech Training," Bloomberg, March 26, 2015, http://www.bloomberg.com/news/articles/2015-03-26/yale-will-bolstercomputer-science-faculty-after-student-outcry

100. Paul Romer, "Should the Government Subsidize Supply or Demand in the Marktet for Scientists and Engineers," National Bureau of Economic Research, working paper 7723, 2000, http://www.nber.org/papers/w7723.pdf.

101. Ed Lazowska, Eric Roberts, and Jim Kurose, "Tsunami or Sea Change? Responding to the Explosion of Student Interest in Computer Science," presentation for NCWIT 10th Anniversary Summit, May 2014, http://lazowska.cs.washington.edu/NCWIT.pdf.

102. Fermin Leal, "More students are 'college ready' but crowded campuses make it harder to get into CSU," EdSource, December 15, 2015, http://edsource.org/2015/csu-students-access-nursing-college-ready-butthey-face-more-hurdles-getting-into-csu-campuses-and-majors/92068.

103. Carnegie Mellon University Undergraduate Admission, "Undergraduate Admission Statistics," accessed April 22, 2016, http://admission.enrollment.cmu.edu/pages/undergraduate-admission-statistics.

104. Patrick Thibodeau, "Career alert: A Master of analytics degree is the ticket -- if you can get into class," Computer World, April 24, 2014, http://www.computerworld.com/article/2488544/it-careers/careeralert--a-master-of-analytics-degree-is-the-ticket----if-you-can-get-into-class.html; Andrew Knudson, Quora discussion board response, "What are the admission statistics for top schools in computer science, information science and computer engineering?, accessed April 22, 2016, https://www.quora.com/Whatare-the-admission-statistics-for-top-schools-in-computer-science-information-science-and-computerengineering.

105. Quora discussion thread, "Is it hard to get 3.3 GPA for CS in UC, Berkeley?" updated June 15, 2016, accessed March 15, 2016, https://www.quora.com/Is-it-hard-to-get-3-3-GPA-for-CS-in-UC-Berkeley; Berkeley Reddit thread, "Concern about declaring L\&S CS Major,” accessed March 15, 2016, https://www.reddit.com/r/berkeley/comments/333ovy/concern_about_declaring_ls_cs_major/.

106. Taylor Soper, "Here's how many freshmen want to study computer science at the University of Washington," Geekwire, May 19, 2014, http:/www.geekwire.com/2014/uw-computer-science-majors/.

107. Judith Gal-Ezer, Vilner, T., \& Zur, E. (2003). Characteristics of students who failed (or succeeded) the introductory CS course. Paper presented at the FIEE 2003 Conference. Boulder, CO. Retrieved April 9, 2008 from http://fie.engrng.pitt.edu/fie2003/http://fie.engrng.pitt.edu/fie2003/; Wilson, B. C. (2002). A study of factors promoting success in computer science including gender differences. Computer Science Education, 12(1-2), 141-164; http://dl.acm.org/citation.cfm?id=1288589.

108. University of Maryland, College Park, Office of the President, "Proposal for Affordable Flagship Excellence, Access, and State Economic Growth: Differential Pricing of Degrees in Business, Engineering, and Computer Science at UMCP," May 1, 2015, http://www.umd.edu/Flagship2020/pdf/Differential\%20pricing,\%20UMCP\%20proposal,\%205-115.pdf; "Additional Tuition Information: Supplemental tuition information for business, engineering and computer science majors," University of Maryland website, accessed March 31, 2016, https://www.admissions.umd.edu/costs/DifferentialTuition.php. 
109. Ibid.

110. Jordan Weissman, "Should Science Majors Pay Less for College Than Art Majors? ," The Atlantic, November 5, 2012, http://www.theatlantic.com/business/archive/2012/11/should-science-majors-payless-for-college-than-art-majors/264417/

111. John Lauerman, "Ballmer Gives Harvard Donation to Expand Computer Science," Bloomberg Technology, November 13, 2014, http:/www.bloomberg.com/news/articles/2014-11-13/ballmer-givesharvard-donation-to-expand-computer-science.

112. Maggie Johnson and Chris Busselle, "Google Computer Science Capactiy Awards," Google Research Blog, March 16, 2015, http://googleresearch.blogspot.com/2015/03/google-computer-science-capacityawards.html.

113. Soper, "The exploding demand for computer science education;" Sarah McBride, "Computer science now top major for women at Stanford University," Reuters, October 9, 2015, http://www.reuters.com/article/us-women-technology-stanford-idUSKCN0S32F020151009.

114. Georgia Tech College of Computing Website, Online Master of Science Computer Science (OMS CS), "The Numbers," accessed May 11, 2016, http://www.omscs.gatech.edu/prospective-students/numbers.

115. Ibid; Carl Straumsheim, "The First Cohort: AT\&T employees, men and domestic students dominate the first cohort of Georgia Tech's new fully online master's degree program," Inside Higher Ed, December 13, 2013, https:/www.insidehighered.com/news/2013/12/13/georgia-tech-admits-first-cohort-ahead-onlinemasters-degree-program-launch.

116. Code.org website, "About," accessed May 11, 2016, https://code.org/about.

117. Code.org website, "Educate," accessed May 11, 2016, https://code.org/educate; Code.org website, "Action," accessed May 11, 2016, https://code.org/action.

118. Julie Bort, “Oracle is donating $\$ 200$ million to Obama's program to teach kids computer science," Business Insider, April 13, 2016, http://www.businessinsider.com/oracle-gives-200-million-to-cs-program2016-4.

119. Emma Brown, "Top business leaders, 27 governors, urge Congress to boost computer science education," Washington Post, April 26, 2016, https:/www.washingtonpost.com/local/education/top-business-leaders27-governors-urge-congress-to-boost-computer-science-education/2016/04/25/f161 cbde-0ae7-11e6bfa1-4efa856caf2a_story.html.

120. Simon Jones, "Computing at School International comparisons" (Microsoft Research UK, November, 2011), http://www.computingatschool.org.uk/data/uploads/internationalcomparisons-v5.pdf.

121. Judith Gal-Ezer et. al, "A High-School Program in Computer Science," IEEE Computer Society, Issue No.10, October, 1995, http://www.openu.ac.il/personal_sites/download/galezer/high-schoolprogram.pdf.

122. Hava Klein-Avishai, Michal Ophir and Yelena Krol, "The Higher Education System in Israel" (The Planning and Budgeting Committee, Council for Higher Education, May 2014), http://che.org.il/wpcontent/uploads/2012/05/HIGHER-EDUCATION-BOOKLET.pdf; National Center for Education Statistics, "Fast Facts: Back to school statistics," accessed April 2, 2015, http://nces.ed.gov/fastfacts/display.asp?id=372.

123. "A is for algorithm: A global push for more computer science in classrooms is starting to bear fruit," The Economist, April 26, 2014, http://www.economist.com/news/international/21601250-global-push-morecomputer-science-classrooms-starting-bear-fruit.

124. Sam Chambers, "Why Schools in England Are Teaching 5-Year-Olds How to Code," GlobalTech, October 15, 2014, http:/www.bloomberg.com/news/2014-10-15/why-schools-in-england-are-teaching5-year-olds-how-to-code.html.

125. Ibid.

126. Romer, "Should the Government Subsidize Supply or Demand."

127. "Computer Science and Technology in Public School Task Force: Initial Report of Activities, Findings, and Recommendations" (Arkansas Department of Education, November, 2015), http://ee-governor2015.ark.org/images/uploads/ComputerScienceandTechnologyinPublicSchoolTaskForceNovember 1201 5ReportFinal.pdf.

128. Liana Heitin, "Virginia Could Be First State to Require All K-12 Students to Learn Computer Science," Education Week, May 10, 2016, http://blogs.edweek.org/edweek/curriculum/2016/04/virginia_could_become_first_state_require_K12_c omputer_science.html. 
129. Megan Smith, "Computer Science for All, The White House Blog, January 30, 2016, https://www.whitehouse.gov/blog/2016/01/30/computer-science-all.

130. "FACT SHEET: President Obama Announces Computer Science For All Initiative," White House Office of the Press Secretary, press release, January 30, 2016, https:/www.whitehouse.gov/the-pressoffice/2016/01/30/fact-sheet-president-obama-announces-computer-science-all-initiative-0.

131. Sharon Lynch, "Science for All: A new breed of schools is closing achievement gaps among students and may hold the key to a revitalized 21st-century workforce," Scientific America, August 1, 2015, http://www.scientificamerican.com/article/science-for-all/.

132. Maggie Johnson and Chris Busselle, "Google Computer Science Capactiy Awards," Google Research Blog, March 16, 2015, http://googleresearch.blogspot.com/2015/03/google-computer-science-capacityawards.html.

133. Robert Atkinson and Merrilea Mayo, "Refueling the U.S. Innovation Economy" (Information Technology and Innovation Foundation, 2010), http://www.itif.org/files/2010-refueling-innovationeconomy.pdf.

134. Allan Fisher and Jane Margolis, "Unlocking the Clubhouse: the Carnegie Mellon Experience," Women and Computing 34, no. 2 (June 2002): 79-83; http://dl.acm.org/citation.cfm?id=543836. 


\section{ACKNOWLEDGMENTS}

The authors wish to thank the following individuals for providing input to this report: Stephen Ruth, Ed Lazowska, Alison Derbenwick Miller, Cameron Wilson, Pat Yongpradit, Renee Dopplick, Sepi Hejazi Moghadam, and Barbara Ericson. Any errors or omissions are the authors' alone.

\section{ABOUT THE AUTHORS}

Adams Nager is an economic policy analyst at ITIF. He researches and writes on innovation economics, manufacturing policy, and the importance of STEM education and high-skilled immigration. Nager holds an M.A. in political economy and public policy and a B.A. in economics, both from Washington University in St. Louis.

Robert D. Atkinson is the founder and president of ITIF. Atkinson's books include Innovation Economics: The Race for Global Advantage (Yale, 2012), Supply-Side Follies: Why Conservative Economics Fails, Liberal Economics Falters, and Innovation Economics is the Answer (Rowman \& Littlefield, 2006), and The Past And Future Of America's Economy: Long Waves Of Innovation That Power Cycles Of Growth (Edward Elgar, 2005). Atkinson holds a Ph.D. in city and regional planning from the University of North Carolina, Chapel Hill, and a master's degree in urban and regional planning from the University of Oregon.

\section{ABOUT ITIF}

The Information Technology and Innovation Foundation (ITIF) is a nonprofit, nonpartisan research and educational institute focusing on the intersection of technological innovation and public policy. Recognized as one of the world's leading science and technology think tanks, ITIF's mission is to formulate and promote policy solutions that accelerate innovation and boost productivity to spur growth, opportunity, and progress.

FOR MORE INFORMATION, VISIT US AT WWW.ITIF.ORG. 